\title{
Seasonal patterns in utilization of dietary protein by the mussel Mytilus trossulus
}

\author{
D. A. Kreeger* \\ Hatfield Marine Science Center, Oregon State University, Newport, Oregon 97365, USA
}

\begin{abstract}
Utilization of dietary protein by adult mussels Mytilus trossulus collected from Yaquina Bay, Oregon, USA, was measured under controlled laboratory conditions during February, May, August, and November 1991 Mussels were fed ${ }^{14} \mathrm{C}$-labeled protein microcapsules $\left(\left[{ }^{14} \mathrm{C}\right] \mathrm{PM}\right)$, which were added to either laboratory-cultured microalgae or natural seston. Utilization of dietary protein, represented by $\left[{ }^{14} \mathrm{C} J \mathrm{PM}\right.$, was assessed by measuring ${ }^{14} \mathrm{C}$-activities of each component of the mussel's carbon budget and calculating the ingestion rate, digestion efficiency, and assimilation efficiency of $\left[{ }^{14} \mathrm{C}\right] \mathrm{PM}$. Mussels utilized dietary protein differently during the year; ingestion rates during May were more than 3 times greater than during November. Digestion and assimilation efficiencies ranged from 16 to $53 \%$ and 5 to $31 \%$, respectively, and were greatest during February and November. In all experiments, dietary protein was ingested at greater rates and assimilated with lower efficiencies when $\left[{ }^{14} \mathrm{C}\right] \mathrm{PM}$ were fed to mussels in combination with a standard diet of microalgae rather than with naturally occurring seston. However, the seasonal pattern of protein utilization was similar for mussels fed on the 2 diets, suggesting that utilization of dietary protein was not a simple response to seasonal differences in seston composition. Greatest net assimilation rates for $\left[{ }^{14} \mathrm{C} \mid \mathrm{PM}\right.$ occurred just before peâk reproductive condition (May) when more than $90 \%$ of the area in mantle tissue sections was comprised of gametes. Estimated assimilation rates of bioavailable protein by mussels in situ were more than 7 times greater during February than in August, when mussels were less reproductively active. Proteolytic activity of crystalline style and digestive diverticula gut extracts was significantly greater during the period January to March than during July to September. Mussels also conserved assimilated protein from catabolism during the peak in reproductive activity (May), when the ratio of ${ }^{14} \mathrm{C}$-respiration $10{ }^{14} \mathrm{C}$-incorporation was lowest and the ratio of oxygen consumption to nitrogen excretion wäs highest. High assimilation rates of dietary protein and metabolic conservation of assimilated protein during late winter and spring were associated with greatest tissue protein contents during March to May. These results suggest that seasonal variation in the utilization of dietary protein by $M$. trossulus is closely linked to the reproductive cycle.
\end{abstract}

\section{INTRODUCTION}

Suspension-feeding bivalves in temperate climates undergo seasonal cycles in their physiological condition in association with their reproductive cycle (for review, see Gabbott 1976, 1983). The nutritional requirements of these animals may also vary seasonally with their changing reproductive condition; however, little is known about either the nutritional requirements of bivalves or the feeding and digestive mechanisms with which they meet their requirements

- Present address: Plymouth Marine Laboratary Prospect Place, The Hoe, Plymouth, Devon PL1 3DH, United Kingdom according to seasonal variation in the quality and quantity of available food sources (Burt 1955, Van Valkenburg et al. 1978, Chanut \& Poulet 1982, Soniat et al. 1984, Berg \& Newell 1986, Mayzaud et al. 1989, Langdon \& Newell 1990, Asmus \& Asmus 1991, Galvao \& Fritz 1991). Our limited understanding of bivalve nutrition is largely due to difficulties in controlling the composition of experimental diets. The microparticulate, natural diet of bivalves is primarily composed of phytoplankton, which has not been fully replaced with defined, artificial diets (for review, see Langdon et al. 1985).

It is well known that bivalves catabolize different biochemical substrates to varying degrees during the 
year (Bayne \& Newell 1983, Gabbott 1983). Ratios of oxygen consumption to nitrogen excretion ( $\mathrm{O} / \mathrm{N}$ ratios) have been used to determine seasonal changes in the relative catabolism of protein and carbohydrate. Barber \& Blake (1985) found that the scallop Argopecten irradians concentricus showed maximum $\mathrm{O} / \mathrm{N}$ ratios (>22) during the initial stages of gametogenesis, which suggested that protein was being spared from catabolism in favor of carbohydrate catabolism. During other times of the year, O/N ratios of scallops were low $(<10)$, which Barber \& Blake (1985) attributed to protein-based catabolism. Low $\mathrm{O} / \mathrm{N}$ ratios have also been observed in Mytilus edulis, during winter when mussels were stressed by low food availability or at times of the year when mussels have high nutritional requirements associated with reproduction (Bayne \& Thompson 1970, Bayne 1973a, b, Gabbott \& Bayne 1973, Bayne \& Widdows 1978). Greater than $50 \%$ of the dry weight of bivalve eggs is comprised of protein (Gabbott 1983, Gabbott \& Peek 1991), and it is therefore possible that during gametogenesis, bivalves may have an increased requirement for protein.

Previous investigators have studied seasonal changes in protein and energy utilization by mussels using the alga Phaeodactylum tricornutum, which was duallabeled with ${ }^{15} \mathrm{~N}$ and ${ }^{14} \mathrm{C}$ (for review, see Hawkins \& Bayne 1991). Mussels were found to recycle endogenous protein reserves with high efficiency, and Hawkins (1985) suggested that the rate of whole body protein turnover (WBPT) may be regulated to help compensate for short-term fluctuations in exogenous protein availability. Mussels may satisfy their aminonitrogen requirements not just by controlling protein input (exogenous uptake) and output (excretion), but also by the rate of flux of internal protein (recycling). The work of Hawkins \& Bayne (1991) demonstrates that mussels can at least meet short-term (e.g. weeks) changes in amino-nitrogen requirements by adjustments in WBPT. Over the long term (e.g. seasons), however, mussels may need to adjust rates of exogenous protein uptake to meet seasonally variable protein losses due to excretion and reproductive output.

The present study concerns seasonal patterns in the acquisition of dietary protein by a suspension-feeding bivalve. Protein uptake by mussels Mytilus trossulus Gould, 1850 was assessed at different times of the year by measuring in vivo ingestion, digestion and assimilation of microencapsulated, radiolabeled protein, which was added in small quantities $(<25 \%$ dry $w / w)$ to an otherwise unaltered natural diet. This method allows the mussel's acquisition of a defined nutrient, such as protein, to be determined without altering the biochemical composition of natural foods. The observed pattern of protein utilization was then compared to seasonal changes in a variety of physiological charac- teristics of the mussels as well as the composition of experimental and natural diets.

\section{METHODS}

Mussel physiological condition. During January, March, May, July, September, and November 1991, and January 1992, 100 adult (shell height 39 to $45 \mathrm{~mm}$ ) mussels were collected from an intertidal population that naturally occurs on suspended mesh cages adjacent to the Hatfield Marine Science Center, located on Yaquina Bay, Oregon, USA. This population has been genetically characterized using electrophoresis as being comprised entirely of Mytilus trossulus (Dr K. M. Brooks, Pacific Rim Mariculture, Port Townsend, WA; see also Kreeger 1992). Mussels were collected at the same tidal stage ( $3 \mathrm{~h}$ after a low, neap tide, just before mussels were submerged) so that their digestive physiology would be independent of tidal influences (Langton 1975, 1977, Morton 1977, 1983, Hawkins et al. 1983). Mussels were cleaned of both epiphytes and byssus threads, and then placed in a holding tank supplied with a continuous supply of sand-filtered (ca $50 \mu \mathrm{m}$ ) ambient seawater. The following physiological parameters were determined: (1) reproductive condition, (2) proximate biochemical composition (protein, lipid, carbohydrate, and ash contents), (3) condition index, (4) ratio of oxygen consumption to nitrogen excretion ( $\mathrm{O} / \mathrm{N}$ ratio), and (5) gut proteolytic activity. In addition, during February, May, August and November, feeding experiments with radiolabeled protein microcapsules were conducted in order to determine the mussels' rates of ingestion and efficiencies of digestion and assimilation for dietary protein. Procedures for each of these measurements are given below.

Reproductive condition: Gametogenesis in Mytilus edulis is localized in the mantle tissue (Lowe et al. 1982, Newell et al. 1982, Bayne et al. 1978). During each bimonthly survey, mantles were carefully separated from the rest of the body tissues in 25 mussels, and both the wet mantle and wet body tissues were weighed separately. For each animal, one of the mantle lobes was subsampled by cutting a 50 to $150 \mathrm{mg}$ transverse section midway along the anteroposterior axis. Although every attempt was made to sample mantles uniformly, it was not considered essential since Lowe et al. (1982) reported that the fractional volume of mantle occupied by gametes did not differ among mantle sections cut from various regions or angles. Each section was added to $3 \mathrm{ml}$ of fixative comprised of a 15:4:1 mixture of picric acid, formaldehyde and acetic acid. The remainder of each mantle was re-weighed and the total ash-free dry weights (AFDW) of the mantle, remaining body tissues and whole body determined. 
Mantle sections were fixed in the picric acid solution for $24 \mathrm{~h}$, processed through an alcohol/toluene series, embedded in Paraplast wax, and then $6 \mu \mathrm{m}$ sections were stained with hematoxylin/eosin. Reproductive condition was determined by measuring the average fractional area occupied by developing or ripe eggs and sperm in 5 randomly selected areas per section ('mantle gamete area', MGA), using a Java image analysis system (Jandel Video Analysis Software). Hawkins et al. (1985) further refined the method for assessing reproductive condition by multiplying a 'gamete volume fraction' (GVF, proportional to MGA measured here) by the total weight of the gonadal tissue to estimate the total weight of gametes, and this approach was also used here but MGA was used instead of GVF. MGA for each mussel was multiplied by its total mantle AFDW to estimate the AFDW of gametes, which was divided by total AFDW to calculate the proportion of mussel biomass comprised of gametes ('body gamete weight', BGW). BGW and MGA measures were arcsine square root transformed, averaged per sample period, and compared among sample periods by ANOVA and Tukey's HSD multiple range techniques (Sokal \& Rohlf 1969).

Proximate biochemical composition: Tissues from 5 mussels were dissected from shells and separately frozen at $-80^{\circ} \mathrm{C}$ for each bimonthly sample date. Additional tissue samples were collected during radiotracer feeding experiments conducted in February, May, August and November 1992 (see below). After all tissue samples were collected (January 1992), they were freeze-dried, and then separately ground into a powder with a mortar and pestle. Protein, lipid and carbohydrate contents were quantified in each tissue sample, which was first resuspended in $4.5 \mathrm{ml}$ (final volume) distilled $\mathrm{H}_{2} \mathrm{O}$ and homogenized for $15 \mathrm{~s}$ (Ultra Turrax, Model SDT 1810, maximum speed). From each homogenate, $2 \mathrm{ml}$ aliquots were transferred to a second vial for lipid extraction and analyzed using a method modified from Folch et al. (1957). Lipids were twice extracted

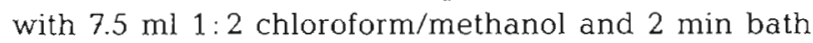
sonication (Braun-Sonic Model 52). Supernatants were collected by centrifugation $(800 \times g, 10 \mathrm{~min})$, combined, treated with $5 \mathrm{ml} 0.7 \% \mathrm{NaCl}$, vortexed at maximum speed for $30 \mathrm{~s}$ (Vortex-Genie, Model 12-812) and allowed to stand overnight at $4{ }^{\circ} \mathrm{C}$. After separation of the aqueous and organic phases, lipid samples were centrifuged $(800 \times \mathrm{g}, 15 \mathrm{~min})$, and $4 \mathrm{ml}$ of the lower organic phase was carefully withdrawn by pipet, added to a baked $\left(450^{\circ} \mathrm{C}, 2 \mathrm{~d}\right)$ and pre-weighed $7 \mathrm{ml}$ vial, and dried for $2 \mathrm{~d}$ at $60^{\circ} \mathrm{C}$ to remove organic solvents. Vials were weighed after drying and amounts of lipid in the original sample were calculated, after correction for losses with tripalmitin (Sigma T-5888) standards which were treated to the same process.
The remainder of each tissue homogenate $(2.5 \mathrm{ml})$ was treated with $4 \mathrm{ml} 5 \%$ trichloroacetic acid (TCA), vortexed for $30 \mathrm{~s}$, heated at $90^{\circ} \mathrm{C}$ for $30 \mathrm{~min}$, cooled in an ice bath for $30 \mathrm{~min}$, and centrifuged at $1500 \times \mathrm{g}$ for 20 min. The supernatant was withdrawn and $1 \mathrm{ml}$ used for spectrophotometric determination of carbohydrate using the procedure described by Dubois et al. (1956), standardized with oyster glycogen (Sigma Type II, $\mathrm{G}-8751)$. The pellet was further treated with $3 \mathrm{ml} 0.5 \mathrm{M}$ $\mathrm{NaOH}$, vortexed for $10 \mathrm{~s}$, heated at $90^{\circ} \mathrm{C}$ for $30 \mathrm{~min}$, and allowed to stand overnight at room temperature. Samples were then centrifuged ( $1500 \times g, 10 \mathrm{~min})$, and the protein concentration of the supernatant determined spectrophotometrically using a test kit based on the procedure of Lowry et al. (1951) (Pierce, BCA 23225). The protein content of the tissue homogenate was calculated from standard absorbances of twicepurified mussel protein (Kreeger 1992).

Average protein, lipid, and carbohydrate contents (percentage of total dry weight) in mussel tissues from each beaker were calculated from arcsine square root transformed data and compared statistically among treatments using ANOVA and Tukey's HSD multiple range procedures (Sokal \& Rohlf 1969). To assess whether prolonged freezing affected determination of the biochemical composition of tissue samples, an additional group of 5 mussels was collected during January 1991 and analyzed immediately for proximate composition, and their composition was compared with that of mussels that were stored in a freezer until analysis (April 1992).

Condition index: Condition index was determined using internal shell cavity capacity (ISCC), which has been reported to be more accurate than volumetric measures of condition index (Crosby \& Gale 1990). Condition index (CI) was calculated as follows:

and

$$
\mathrm{ISCC}=\mathrm{TWW}-\mathrm{DSW}
$$

$$
C I=(A F D T W \times 1000) / I S C C
$$

where total wet weight (TWW), dry shell weight (DSW), ash-free dry tissue weight (AFDTW), and ISCC were measured in grams, and CI was therefore unit-less. Ten mussels were analyzed for CI for each sample period. Shell heights of mussels were first measured, and shells were then dabbed dry for measurement of TWW. Mussel tissues were dissected from shells, and tissues and shells were freeze-dried separately in preweighed vials, and then re-weighed. Tissues were ashed at $450^{\circ} \mathrm{C}$ for $2 \mathrm{~d}$ in pre-weighed vials and reweighed for calculation of AFDTW. Condition indices were compared among samples with ANOVA and Tukey's HSD multiple ranges test (Sokal \& Rohlf 1969).

$O / N$ ratios: At each sample period, 15 mussels were held for $18 \mathrm{~h}$ in $0.2 \mu \mathrm{m}$ filtered seawater at ambient temperature to allow gut purging. Rates of ammonia 
nitrogen excretion and oxygen consumption were measured for individual mussels using the technique of Kreeger \& Langdon (1993). Tissues from each mussel were analyzed for AFDTW as described above. Rates of oxygen consumption and nitrogen excretion for each mussel were expressed per gram AFDTW, converted to weight atomic units, averaged among replicates, and then compared directly for calculation of $\mathrm{O} / \mathrm{N}$ ratios. Oxygen consumption rates, nitrogen excretion rates and $\mathrm{O} / \mathrm{N}$ ratios were compared seasonally by ANOVA and Tukey's HSD multiple range procedures (Sokal \& Rohlf 1969).

Gut proteolytic activity: Immediately after each collection, 28 mussels were dissected on ice and their crystalline styles were combined into 4 groups of 7 . Each group of styles was added to a pre-weighed and pre-ashed $\left(450^{\circ} \mathrm{C}, 2 \mathrm{~d}\right)$ glass vial held on ice to slow style dissolution. Vials were weighed and to each was added a sufficient volume of sterile $(0.45 \mu \mathrm{m}$ filtered, 100 ppm Thimerosal) seawater at $\mathrm{pH} 7$ (buffered with $0.05 \mathrm{M}$ Tris- $\mathrm{HCl}$ ) to give $100 \mathrm{mg}$ wet style weight $\mathrm{ml}^{-1}$. Vials were immediately frozen at $-80^{\circ} \mathrm{C}$. Approximately $20 \mathrm{mg}$ wet weight of tissue from the digestive diverticula of each mussel was also sampled and treated in the same way as crystalline style samples, except that the seawater was buffered to $\mathrm{pH}$ 6. The $\mathrm{pH}$ values used for style and diverticula samples were based on typical $\mathrm{pH}$ values reported for the stomach and diverticula in other bivalve species (Mathers 1974, Reid 1982, Seiderer et al. 1982, Trainer \& Tillinghast 1982, Brock et al. 1986).

Style and diverticula samples were stored at $-80^{\circ} \mathrm{C}$ until all samples were collected, and their proteolytic activity was measured concurrently in April 1992. To assess the effects of prolonged freezing (up to $14 \mathrm{mo}$ ) on proteolytic activity, an additional group of 28 mussels was collected at the first sample period in January 1991, but their styles and diverticula were not frozen; the proteolytic activity was measured immediately using the same procedure used in April 1992. Proteolytic activity measured in January 1991 was compared ( $t$-tests) to the activity of frozen samples from the same group of mussels to assess whether freezing and storage significantly affected enzyme activity.

Proteolytic activities of style and diverticula samples were measured by the dissolution of $\left[{ }^{14} \mathrm{C}\right.$ lprotein from $\left[{ }^{14} \mathrm{C}\right]$ protein microcapsules $\left(\left[{ }^{14} \mathrm{C}\right] \mathrm{PM}\right)$. Capsules used for this test were identical to those used in the ${ }^{14} \mathrm{C}$ feeding experiments outlined below. $\left[{ }^{14} \mathrm{C}\right] \mathrm{PM}$ were incubated with gut preparations using procedures of Kreeger (1992). Thawed samples of styles and diverticula were homogenized for $15 \mathrm{~s}$ while being chilled with ice. After centrifugation $(1500 \times g, 15$ min, under refrigeration), $100 \mu \mathrm{l}$ of supernatant was added to a $1 \mathrm{ml}$ capsule suspension for $24 \mathrm{~h}$ incubation. Methods for sample incubation and ${ }^{14} \mathrm{C}$-analysis were those of Kreeger (1992). Proteolytic activities of style and diverticula extracts were standardized by incubating 5 additional samples of $\left[{ }^{14} \mathrm{CJPM}\right.$ with commercially purchased trypsin possessing a total of 1000 units proteolytic activity (Kreeger 1992), so that ${ }^{14} \mathrm{C}$-dissolution rates could be expressed as equivalent trypsin units per mg wet sample (style or diverticula) weight. Seasonal variability in the proteolytic activity of style and diverticula extracts was assessed by ANOVA (Sokal \& Rohlf 1969). The proteolytic activity associated with the diverticula should be interpreted with caution because diverticula samples could have been contaminated with non-digestive, lysosomal enzymes (for review, see Morton 1983).

Feeding experiments with ${ }^{14}$ C-labeled protein microcapsules: Ingestion rates and assimilation efficiencies of Mytilus trossulus fed on ${ }^{14} \mathrm{C}$-labeled protein microcapsules $\left(\left[{ }^{14} \mathrm{C}\right] \mathrm{PM}\right)$ were measured in 4 feeding experiments conducted during February, May, August, and November 1991, using previously described methods (Kreeger et al. 1988, 1990, Kreeger 1992). Adult mussels (39 to $45 \mathrm{~mm}$ shell helght) were collected $1 \mathrm{wk}$ prior to each experiment, cleaned, and acclimated to $12^{\circ} \mathrm{C}$ under intertidal conditions $(6 \mathrm{~h}$ of aerial exposure per $12 \mathrm{~h}$ ). Experiments were also conducted at $12^{\circ} \mathrm{C}$, which was within $3^{\circ} \mathrm{C}$ of ambient temperatures at the time of mussel collections.

A mixture of protein from crabs $(94 \% \mathrm{w} / \mathrm{w})$ and $\left[{ }^{14} \mathrm{C}\right]$ protein from microalgae $(6 \% \mathrm{w} / \mathrm{w})$ was encapsulated to prepare $\left[{ }^{14} \mathrm{C}\right] \mathrm{PM}$ (Kreeger 1992). One batch of $\left[{ }^{14} \mathrm{C}\right] \mathrm{PM}$ having high ${ }^{14} \mathrm{C}$-specific activity $\left(1.12 \times 10^{5}\right.$ $\mathrm{dpm} \mathrm{mg}^{-1}$ ) was prepared in advance and delivered at the same concentration $\left(1.15 \times 10^{5} \mathrm{dpm}^{-1}\right)$ in all experiments. $\left[{ }^{14} \mathrm{C}\right.$ ]PM were added to each of 2 different, nonradioactive diets in each experiment. The first diet consisted of freeze-killed microalgae (Isochrysis galbana, clone T-ISO), prepared and rationed using the procedure of Kreeger (1992). As with the capsules, the algal diet was prepared in advance of this study so that diet quality would be consistent among experiments. Freeze-killing algae also served to prevent recycling of ${ }^{14} \mathrm{CO}_{2}$ in the feeding system. The second non-radioactive diet consisted of natural seston collected just prior to each experiment. The natural composition of seston was not altered except that particles greater than $150 \mu \mathrm{m}$ were removed by sieving to prevent clogging of the feeding system and to remove zooplankton. Seston was collected $3 \mathrm{~h}$ after low tide in $20 \mathrm{l}$ polyethylene carboys from Yaquina Bay, and its temperature was adjusted to $12^{\circ} \mathrm{C}$. Both algal and seston diets were routinely sampled $(500 \mathrm{ml})$ and filtered onto Whatman $\mathrm{GF} / \mathrm{C}$ filters for weight-on-ignition analysis (dried $60^{\circ} \mathrm{C}, 2 \mathrm{~d}$; ashed $450^{\circ} \mathrm{C}, 2 \mathrm{~d}$ ) of dietary concentrations of particulate organic material. 
During acclimation, mussels were separated into 2 groups, which were fed either microalgae or natural seston. During experimentation, mussels were fed the same diet (algae or seston) as during acclimation, except that both diets also received a standard ration of $\left[{ }^{14} \mathrm{C}\right] \mathrm{PM}$, which comprised less than $25 \%$ of the total dry diet weight. Therefore, the overall quality of acclimation and experimental diets was similar, which potentially avoided a change in mussel digestive physiology in reaction to altered food quality (e.g. Bayne et al. 1984). If mussels utilized $\left[{ }^{14} \mathrm{C}\right] P M$ differently during the year, but only when fed natural seston (variable in composition among experiments) and not when fed algae (constant in composition among experiments), then this would suggest that seasonal variation in seston composition was important in determining seasonal patterns in dietary protein utilization. On the other hand, if seasonal patterns in $\left[{ }^{14} \mathrm{C}\right.$ JPM utilization occurred regardless of whether the diet was primarily algae or seston, then it is likely that physiological factors, such as changes in the mussel's protein requirements, were predominantly responsible for determining protein utilization.

Full methods for conducting the feeding experiments have been described by Kreeger (1992). During each experiment, 16 mussels were individually fed $\left[{ }^{14} \mathrm{C}\right] \mathrm{PM}$ in combination with either algae (8 mussels) or seston ( 8 mussels) in a continuous flow system. Mussels were fed the ${ }^{14} \mathrm{C}$-labeled diets during a $6 \mathrm{~h}$ period of submergence, then exposed to air for $6 \mathrm{~h}$, and then fed a non-labeled diet during a second $6 \mathrm{~h}$ period of submergence. Utilization of $\left[{ }^{14} \mathrm{C}\right] \mathrm{PM}$ by each mussel was assessed by quantifying its complete ${ }^{14} \mathrm{C}$-budget, including weight-specific ${ }^{14} \mathrm{C}$-activities defecated $(F)$, solubilized and then defecated (digested fecal material; $S_{\mathrm{fec}}$ ), solubilized and released into the effluent (digested non-fecal material; $\left.S_{\text {eff }}\right)$, respired $(R)$, or incorporated into mussel tissue $(T)$. Ingestion $(I)$ of ${ }^{14} \mathrm{C}$ was calculated by summation of ${ }^{14} \mathrm{C}$-activities associated with all components of the ${ }^{14} \mathrm{C}$-budget $\left(F+S_{\text {eff }}+R+T\right)$. Digestion efficiency was calculated as the proportion of ingested ${ }^{14} \mathrm{C}$ that was digested $\left[\left(S_{\mathrm{fec}}+S_{\mathrm{eff}}+R+T\right) / I\right.$ $\times 100 \%$. Assimilation efficiency was calculated as the proportion of ingested ${ }^{14} \mathrm{C}$ that was either respired or incorporated $[(R+T) / I \times 100 \%]$. Assimilation efficiency may have been underestimated if a portion of soluble ${ }^{14} \mathrm{C}$ in feces $\left(S_{\mathrm{fec}}\right)$ or effluents $\left(S_{\mathrm{eff}}\right)$ was postmetabolic (e.g. Hawkins et al. 1985).

Weight-specific ${ }^{14} \mathrm{C}$-activities of each ${ }^{14} \mathrm{C}$-budget component were also expressed as a percentage of weight-specific ingested ${ }^{14} \mathrm{C}$-activities to better compare post-ingestion patterns of protein utilization (Kreeger 1992). These percentages, as well as digestion and assimilation efficiencies, were arcsine square root transformed before statistical analyses (Sokal \&
Rohlf 1969). For each experiment, components of the mussel's ${ }^{14} \mathrm{C}$-budget were compared between dietary treatments with $t$-tests (Sokal \& Rohlf 1969). In addition, a 2-way ANOVA (Sokal \& Rohlf 1969) was used to differentiate the significance of the main effects of diet type and season.

Protein bioavailability in the seston. Suspensionfeeding bivalves can potentially acquire protein from a variety of particulate foods including both detritus and phytoplankton (for reviews, see Bayne \& Newell 1983, Langdon \& Newell 1990); however, the digestibilities of detrital and algal protein are not equal (e.g. Rice 1982, Hicks et al. 1991). To obtain a biologically meaningful estimate of the availability of particulate protein in Yaquina Bay throughout the year, seston was periodically collected, frozen, and later exposed to digestive enzymes from the gut of Mytilus trossulus, and resulting concentrations of dissolved protein were quantified. It should be noted that this method might have underestimated bioavailable protein concentrations if the protein assay did not accurately quantify low-molecular-weight breakdown products (e.g. polypeptides, amino acids), which might have been used by mussels (Manahan et al. 1982, Wright 1982, 1988); however, even if protein concentrations were underestimated, seasonal variation in relative concentrations would still have been accurate.

Seston was collected bimonthly when mussels were sampled for physiological condition (see above). Seston was collected $3 \mathrm{~h}$ after low neap tide, so that extraneous influences of tidal height on food availability were eliminated. Ten replicate, known volumes of seawater (500 to $1000 \mathrm{ml}$ ) were vacuum-filtered (20 psi) through pre-weighed and ashed $\left(450^{\circ} \mathrm{C}, 2 \mathrm{~d}\right.$ ) Whatman GF/C filters per sample period. Each filter was rinsed with $10 \mathrm{ml} 0.5 \mathrm{M}$ ammonium formate to remove salts, temporarily stored at $-80^{\circ} \mathrm{C}$, and freezedried. Dried filters were weighed, and 5 from each sample period were ashed at $450^{\circ} \mathrm{C}$ for $2 \mathrm{~d}$, reweighed, and the concentration of particulate organic matter (POM) was calculated. The remaining 5 filters were cut into thin strips and each was added to $4 \mathrm{ml}$ of sterile $(0.2 \mu \mathrm{m}$ filtered, $100 \mathrm{ppm}$ Thimerosal), $\mathrm{pH} 7$ buffered $(0.05 \mathrm{M}$ Tris $\mathrm{HCl}$ ) seawater in a $15 \mathrm{ml}$ polycarbonate test tube. A $500 \mu \mathrm{l}$ aliquot of crystalline style extract (prepared from styles collected from 200 mussels using techniques described above) was also added to each tube. Five replicate test tubes that did not contain filters also received sterile seawater and enzyme solutions as controls for background protein concentrations (dissolved protein in seawater and interference of the protein assay by the style extract). Samples were incubated for $24 \mathrm{~h}$ on a shaker table (Lab-Line Orbit Shaker, Model 3590) and centrifuged $(1500 \times g, 20 \mathrm{~min})$. From each test tube, $100 \mu \mathrm{l}$ of 
supernatant was used to measure proteins with a test kit (Pierce BCA 23225) based on the method of Lowry et al. (1951).

Protein concentrations were calculated from absorbances of algal protein standards (from Isochrysis

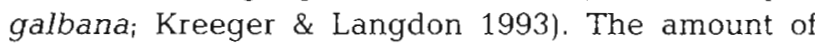
protein measured in controls (no filters) was subtracted from each sample (with filters). It is important to note that production of protein from filtered material may not have been due solely to the enzymatic activity from the style extract because the physical activity of the shaker table and freezing effects could have been sufficient to rupture cells of microorganisms and release protein. The control-corrected amount of protein released from filtered seston by physical and enzymatic processes was assumed to be an approximation of 'bioavailable' protein.

\section{RESULTS}

\section{Mussel physiological condition}

\section{Reproductive condition}

The reproductive condition of Mytilus trossulus in Yaquina Bay was significantly (ANOVA, p < 0.0001) greater during May 1991 than at any other time of year (Fig. 1). Both the proportion of mantle gonadal tissue occupied by developing or ripe gametes (MGA) and the proportion $(\mathrm{w} / \mathrm{w})$ of dry tissue comprised of gametes (BGW) peaked during May (significant, $p<0.05$ ). A proportion of the mussel population was in spawning condition at all times of the year.

\section{Proximate biochemical condition}

The protein content of mussel tissues varied significantly $(p=0.004)$, being greatest during the spring (e.g. $57 \%$ in March) and lowest during summer and fall (e.g. $44 \%$ in September) (Fig. 2). The lipid content also peaked during April and May (Fig. 2); however, seasonal variation in lipid content was not significant $(\mathrm{p}>0.05)$. In contrast to protein and lipid, carbohydrate content was lowest during late winter and spring $(<10 \% \mathrm{w} / \mathrm{w})$ and gradually increased during summer and fall (significant, $p<0.0001)$. Greatest carbohydrate content $(29 \%)$ occurred in November (Fig. 2).

\section{Condition index}

The seasonal pattern in the condition index of Mytilus trossulus was similar to that described for the mussel's carbohydrate content. Condition index was significantly ( $p<0.0001)$ greater during the fall (97 in September and 95 in November) than at other times (55 in January 1991, 48 in March, 65 in May, 69 in July, and 67 in January 1992)

\section{$\mathrm{O} / \mathrm{N}$ ratios}

The $\mathrm{O} / \mathrm{N}$ ratio differed significantly $(\mathrm{p}<0.0001)$ among measurements and was greatest $(>50)$ during May and lowest $(<10)$ during November and January (Fig. 3). Seasonal variation in $\mathrm{O} / \mathrm{N}$ ratio was partly attributed to significant $(p<0.0001$ ) differences among

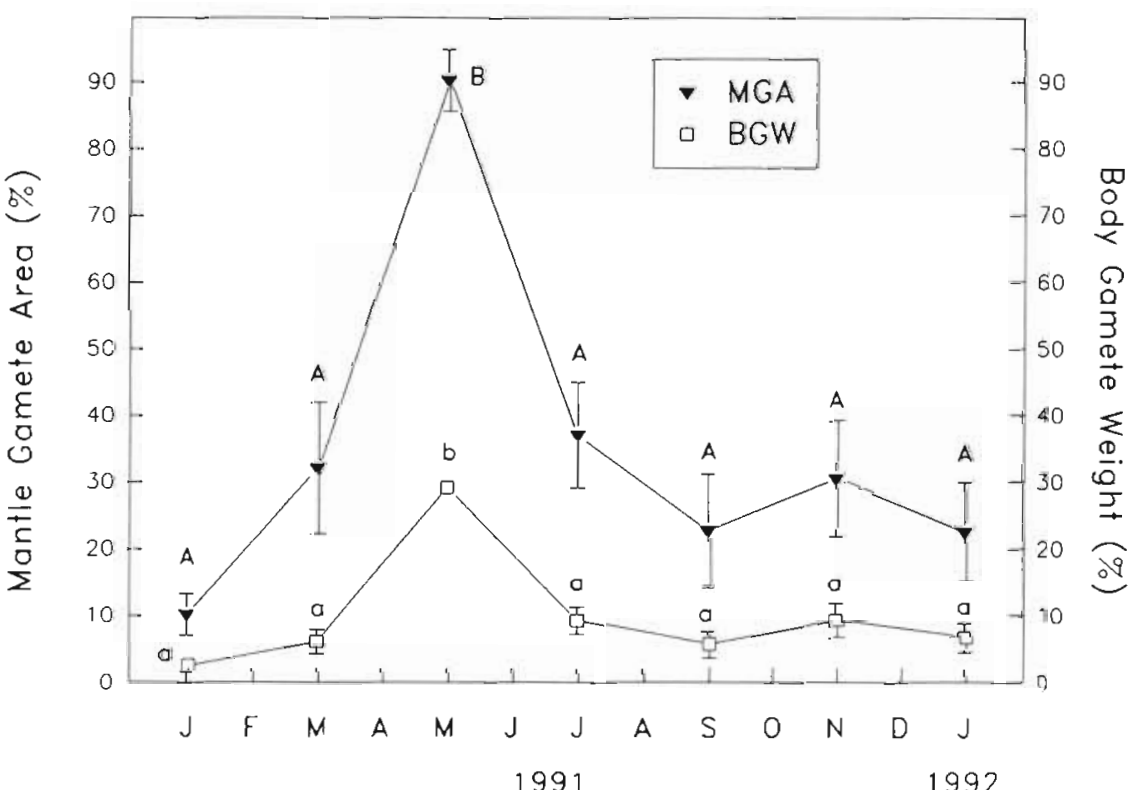

Fig. 1. Mytilus trossulus. Mean $( \pm 95 \%$ confidence intervals) proportion (\% area) of mantle tissue sections occupied by developing or ripe gametes (mantle gamete area, MGA) and the proportion ( $\% \mathrm{w} / \mathrm{w})$ of dry mussel tissue comprised of gametes (body gamete weight, $B G W$ ) in individuals sampled bimonthly from Yaquina Bay, Oregon, between January 1991 and January 1992. Significant $(\alpha=0.05)$ differences among observations are indicated with different letters (upper case for MGA, lower case for BGW) 


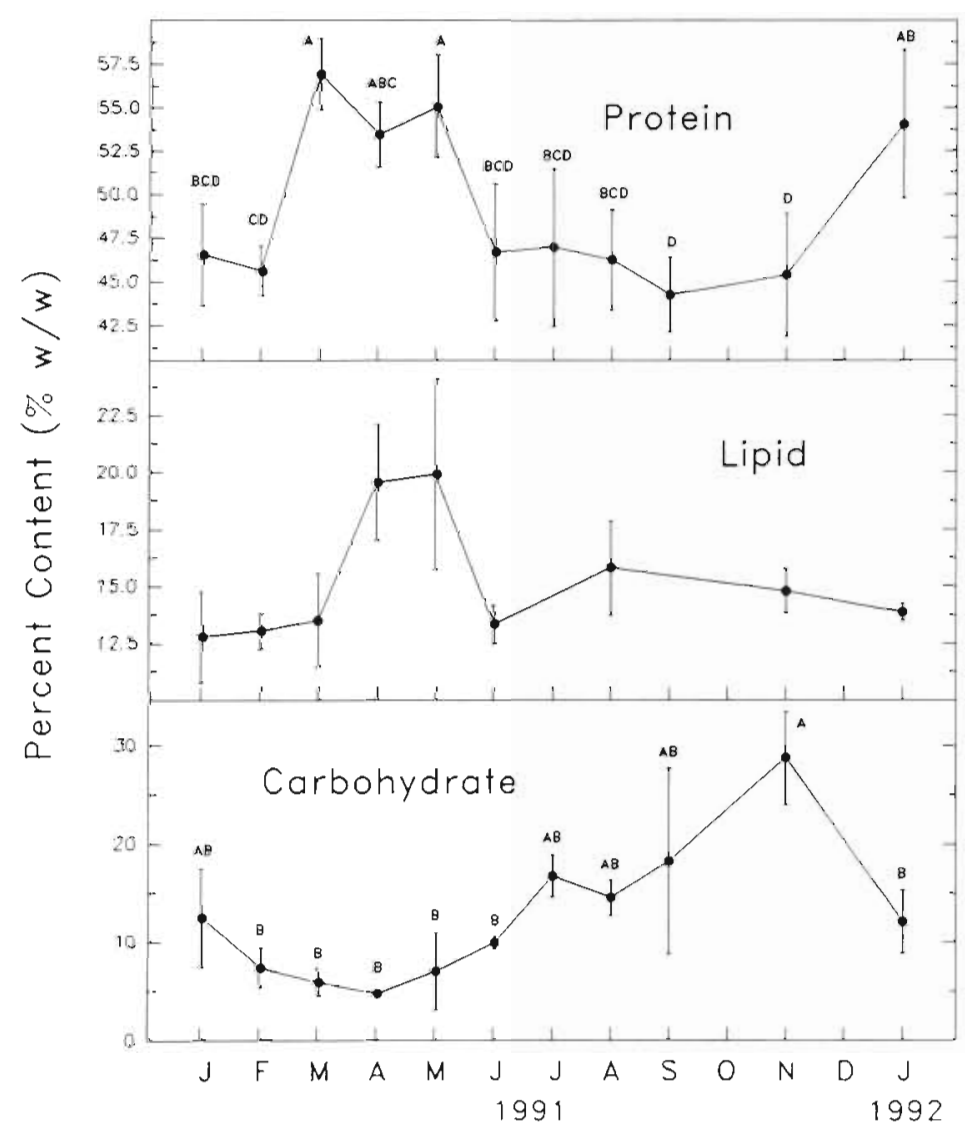

Fig. 2. Mytilus trossulus. Percentage content ( $\%$ total dry weight; $\pm 95 \% \mathrm{Cl}$ ) for protein, lipid and carbohydrate in tissues of mussels collected from Yaquina Bay, Oregon, between January 1991 and January 1992. Significant ( $\alpha=0.05$ ) differences among observations are indicated with different letters

sample times in oxygen consumption, which varied from less than $12 \mu \mathrm{g}$-at. $\mathrm{O}_{2}$ (g AFDTW) ${ }^{-1}$ (November) to greater than $80 \mu \mathrm{g}$-at. $\mathrm{O}_{2}(\mathrm{~g} \text { AFDTW })^{-1}$ (May, July).
Excretion of ammonia nitrogen also varied significantly $(p<0.0001)$ among sample dates, but this variation did not appear to be seasonally correlated with oxygen consumption because the lowest excretion rate /ca $1.5 \mu \mathrm{g}$-at. $\mathrm{NH}_{4}{ }^{+}-\mathrm{N}$ (g AFDTW $)^{-1}$ ] was measured in November and greatest excretion rates [ca 4 $\mu$ g-at. $\mathrm{NH}_{4}{ }^{+}-\mathrm{N} \quad$ (g AFDTW $)^{-1}$ ] were measured during July 1991 and January 1992.

\section{Gut proteolytic activity}

Proteolytic activities measured in crystalline style and digestive diverticula extracts from Mytilus trossulus are expressed as equivalent units of trypsin activity in Fig. 4. Crystalline style proteolytic activity was significantly greater $(p<0.05)$ during January and March than during July, September and November (Fig. 4). Similarly, proteolytic activity in the digestive diverticula was significantly ( $p<0.05$ ) greater during March than during July, September, and November (Fig. 4), although the range in diverticula activity was much less pronounced than the range in style activity. The proteolytic activity of style extracts (77 to 109 trypsin units $\mathrm{mg}^{-1}$ ) was much greater at all times of the year relative to that of diverticula extracts (31 to 37 trypsin units $\mathrm{mg}^{-1}$ ). No significant differences ( $t$-test, $\mathrm{p}>0.05$ ) in the activities of style or diverticula extracts were detected in samples analyzed prior to or after prolonged freezing.
Fig. 3. Mytilus trossulus. Gram atomic ratios of oxygen consumption to ammonia-nitrogen excretion $( \pm 95 \% \mathrm{Cl}$ ) by mussels collected from Yaquina Bay, Oregon, between January 1991 and January 1992. Significant ( $\alpha=0.05$ ) differences among observations are indicated with different letters

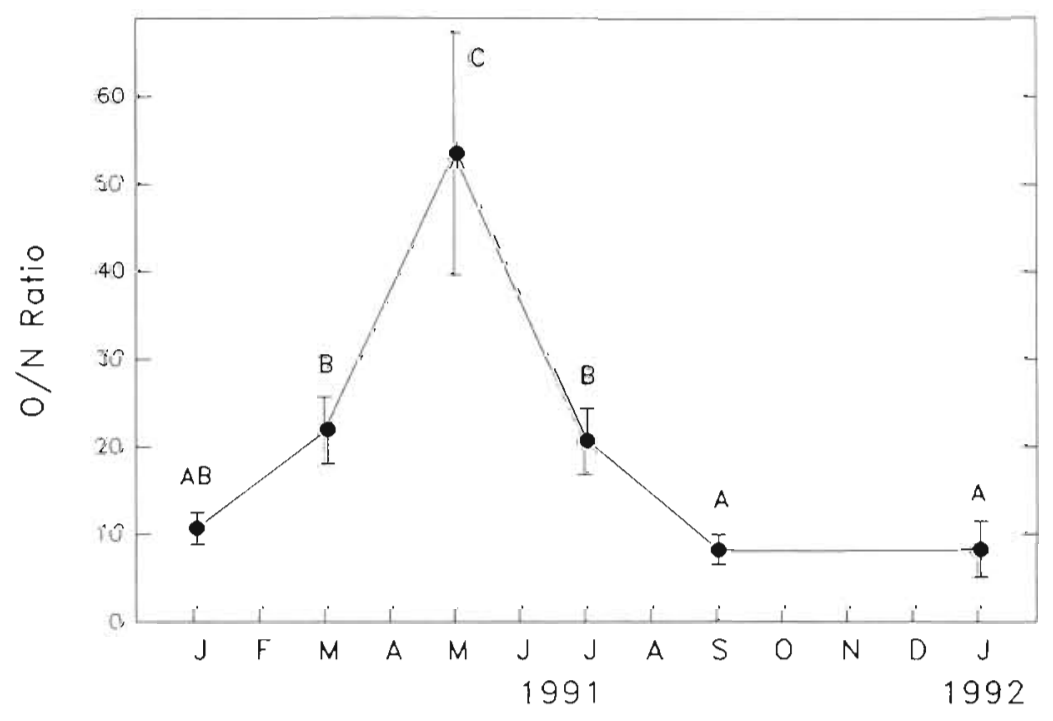




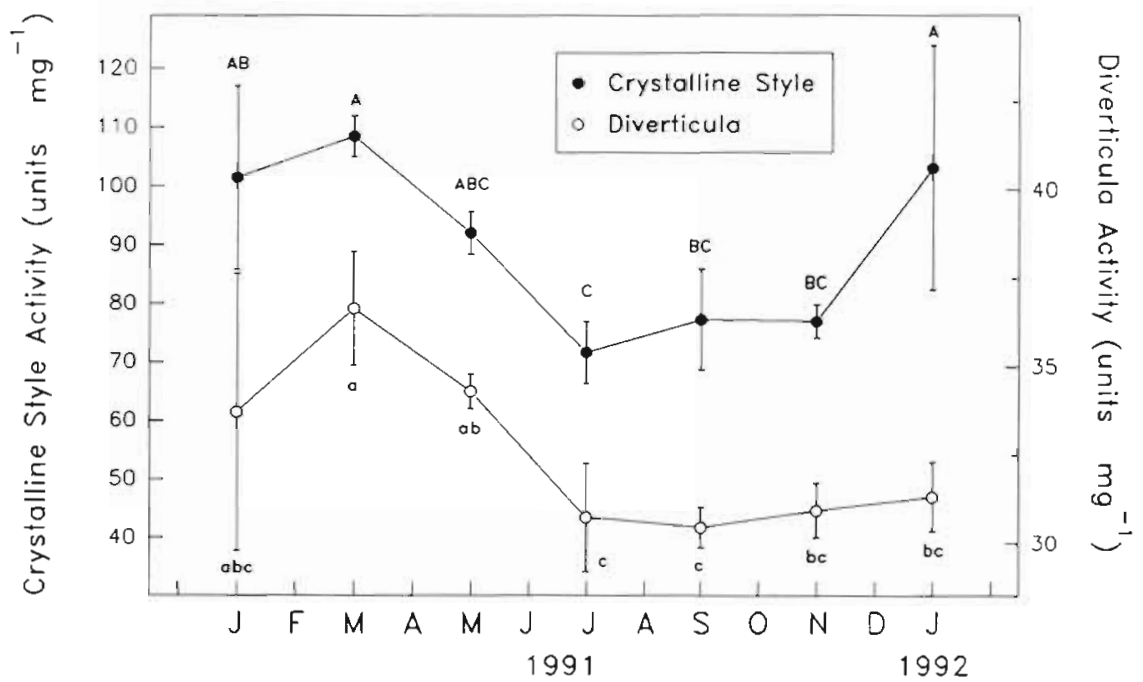

Feeding experiments with ${ }^{14} \mathrm{C}$-labeled protein microcapsules

Utilization of $\left[{ }^{14} \mathrm{C} \mid \mathrm{PM}\right.$ by Mytilus trossulus varied greatly according to both season and to diet type (algae or seston) supplemented with $\left[{ }^{14} \mathrm{C}\right] \mathrm{PM}$. Complete ${ }^{14} \mathrm{C}$. budgets of mussels fed $\left[{ }^{14} \mathrm{C}\right] \mathrm{PM}$ with either algae or seston during February, May, August and November 1991 are given in Table 1. As reported in previous ${ }^{14} \mathrm{C}$ feeding experiments with mussels (Kreeger et al. 1988, 1990 , Kreeger 1992), variation in the absolute ${ }^{14} \mathrm{C}$-specific activities associated with components of the carbon budget was high among individuals within a given treatment. However, when the ${ }^{14} \mathrm{C}$-activity of each component of the ${ }^{14} \mathrm{C}$-budget was expressed as a percentage of ingested ${ }^{14} \mathrm{C}$, variation among individuals was reduced appreciably. For example, weight-specific ingestion of $\left[{ }^{14} \mathrm{C}\right] \mathrm{PM}$ varied among groups of mussels from $3.04 \times 10^{5} \mathrm{dpm}$ (g AFDTW) ${ }^{-1}$ to $11.43 \times 10^{5} \mathrm{dpm}$ (g AFDTW $)^{-1}$, and coefficients of variation associated with these values were as high as $48 \%$. Consequently, weight-specific ${ }^{14} \mathrm{C}$-activities defecated, respired, incorporated and so forth also varied considerably. In contrast, coefficients of variation associated with the percentages of ingested ${ }^{14} \mathrm{C}$ that were either defecated, respired, incorporated, and so forth were $<20 \%$.

Table 1. Mytilus trossulus. Components of the ${ }^{14} \mathrm{C}$-budget of mussels fed $\left[{ }^{14} \mathrm{C}\right.$ ]protein microcapsules with either freeze-killed Isochrysis galbana (T-ISO) or natural seston in February, May, August, and November 1991. Mean ( \pm SD) ${ }^{14} \mathrm{C}$-activity of each component is expressed as a percentage of ingested ${ }^{14} \mathrm{C}$ [actual ${ }^{14} \mathrm{C}$-activities, in $\mathrm{dpm} \times 10^{3}$ (g AFDTW), are given in parentheses]. Differences between groups were assessed with $t$-tests (percentages were arcsine square root transformed before analysis); ns: not significant

\begin{tabular}{|c|c|c|c|}
\hline \multirow{2}{*}{${ }^{14} \mathrm{C}$-budget component } & \multicolumn{2}{|c|}{ Percentage of ingested ${ }^{14} \mathrm{C}$} & \multirow[t]{2}{*}{ t-test, $\mathrm{p}$-value } \\
\hline & Group fed capsules with algae & Group fed capsules with seston & \\
\hline February & $n=6$ & $\mathrm{n}=8$ & \\
\hline Ingestion & $\begin{array}{c}100 \\
(1076 \pm 144)\end{array}$ & $\begin{array}{c}100 \\
(731 \pm 208)\end{array}$ & 0.005 \\
\hline Defecation & $\begin{array}{l}70.3 \pm 8.8 \\
(756 \pm 149)\end{array}$ & $\begin{array}{l}51.6 \pm 9.6 \\
(377 \pm 155)\end{array}$ & $\begin{array}{r}0.018 \\
<0.001\end{array}$ \\
\hline Solubilized in feces (digested) & $\begin{array}{c}6.36 \pm 1.09 \\
(68.4 \pm 28.4)\end{array}$ & $\begin{array}{c}4.30 \pm 1.20 \\
(31.4 \pm 18.8)\end{array}$ & $\begin{array}{c}\text { ns } \\
0.012\end{array}$ \\
\hline Solubilized in effluent (digested) & $\begin{array}{l}13.9 \pm 5.29 \\
(149 \pm 139)\end{array}$ & $\begin{array}{l}17.4 \pm 4.00 \\
(127 \pm 52.2)\end{array}$ & $\begin{array}{l}\text { ns } \\
\text { ns }\end{array}$ \\
\hline Respiration (assimilated) ${ }^{a}$ & $\begin{array}{c}8.09 \pm 1.90 \\
(87.1 \pm 37.3)\end{array}$ & $\begin{array}{l}18.9 \pm 6.70 \\
(138 \pm 120)\end{array}$ & $\begin{array}{l}\text { ns } \\
\text { ns }\end{array}$ \\
\hline Incorporation (assimilated) & $\begin{array}{l}7.82 \pm 1.54 \\
(84.1 \pm 24.0)\end{array}$ & $\begin{array}{c}12.2 \pm 3.07 \\
(89.1 \pm 28.6)\end{array}$ & $\begin{array}{l}\text { ns } \\
\text { ns }\end{array}$ \\
\hline Total digestion & $\begin{array}{l}36.2 \pm 6.55 \\
(389 \pm 145)\end{array}$ & $\begin{array}{l}52.8 \pm 9.76 \\
(386 \pm 134)\end{array}$ & $\begin{array}{c}0.030 \\
\text { ns }\end{array}$ \\
\hline Total assimilation & $\begin{array}{l}15.9 \pm 3.45 \\
(171 \pm 60.0)\end{array}$ & $\begin{array}{l}31.1 \pm 5.68 \\
(227 \pm 89.7)\end{array}$ & $\begin{array}{c}0.008 \\
\text { ns }\end{array}$ \\
\hline
\end{tabular}


Table 1 (continued)

\begin{tabular}{|c|c|c|c|}
\hline \multirow{2}{*}{${ }^{14} \mathrm{C}$-budget component } & \multicolumn{2}{|c|}{ Percentage of ingested ${ }^{14} \mathrm{C}$} & \multirow{2}{*}{$t$-test, $\mathrm{p}$-value } \\
\hline & Group fed capsules with algae & Group fed capsules with seston & \\
\hline May & $\mathrm{n}=8$ & $\mathrm{n}=6$ & \\
\hline Ingestion & $\begin{array}{c}100 \\
(1142 \pm 337)\end{array}$ & $\begin{array}{c}100 \\
(606 \pm 150)\end{array}$ & $0 . \overline{-}$ \\
\hline Defecation & $\begin{array}{l}82.1 \pm 19.3 \\
(937 \pm 300)\end{array}$ & $\begin{array}{l}72.4 \pm 7.08 \\
(439 \pm 139)\end{array}$ & $\begin{array}{c}\text { ns } \\
0.003\end{array}$ \\
\hline Solubilized in feces (digested) & $\begin{array}{c}3.36 \pm 0.97 \\
(38.4 \pm 24.4)\end{array}$ & $\begin{array}{c}2.38 \pm 0.71 \\
(14.4 \pm 5.43)\end{array}$ & $\begin{array}{c}\text { ns } \\
0.037\end{array}$ \\
\hline Solubilized in effluent (digested) & $\begin{array}{c}7.92 \pm 0.99 \\
(90.5 \pm 28.1)\end{array}$ & $\begin{array}{c}14.6 \pm 4.44 \\
(88.7 \pm 70.8)\end{array}$ & $\begin{array}{l}\text { ns } \\
\text { ns }\end{array}$ \\
\hline Respiration (assimilated) $^{a}$ & $\begin{array}{c}2.33 \pm 0.43 \\
(26.6 \pm 10.4)\end{array}$ & $\begin{array}{c}3.81 \pm 0.88 \\
(23.1 \pm 7.13)\end{array}$ & $\begin{array}{c}0.035 \\
\text { ns }\end{array}$ \\
\hline Incorporation (assimilated) & $\begin{array}{c}7.73 \pm 2.07 \\
(88.3 \pm 44.2)\end{array}$ & $\begin{array}{c}9.09 \pm 2.16 \\
(55.1 \pm 14.7)\end{array}$ & $\begin{array}{l}\text { ns } \\
\text { ns }\end{array}$ \\
\hline Total digestion & $\begin{array}{l}21.4 \pm 2.30 \\
(244 \pm 61.0)\end{array}$ & $\begin{array}{l}30.0 \pm 5.48 \\
(182 \pm 55.4)\end{array}$ & $\begin{array}{c}0.035 \\
\text { ns }\end{array}$ \\
\hline Total assimilation & $\begin{array}{l}10.1 \pm 2.35 \\
(115 \pm 50.6)\end{array}$ & $\begin{array}{c}13.0 \pm 2.96 \\
(78.5 \pm 19.2)\end{array}$ & $\begin{array}{l}\text { ns } \\
\text { ns }\end{array}$ \\
\hline August & $\mathrm{n}=8$ & $\mathrm{n}=8$ & \\
\hline Ingestion & $\begin{array}{c}100 \\
(668 \pm 322)\end{array}$ & $\begin{array}{c}100 \\
(346 \pm 127)\end{array}$ & $\overline{-}-\overline{0} 19$ \\
\hline Defecation & $\begin{array}{l}86.2 \pm 4.31 \\
(576 \pm 301)\end{array}$ & $\begin{array}{l}83.0 \pm 6.02 \\
(287 \pm 116)\end{array}$ & $\begin{array}{c}\text { ns } \\
0.024\end{array}$ \\
\hline Solubilized in feces (digested) & $\begin{array}{c}2.34 \pm 1.20 \\
(15.6 \pm 19.7)\end{array}$ & $\begin{array}{c}0.39 \pm 0.30 \\
(1.34 \pm 3.15)\end{array}$ & $\begin{array}{l}\text { ns } \\
\text { ns }\end{array}$ \\
\hline Solubilized in effluent (digested) & $\begin{array}{c}7.56 \pm 1.58 \\
(50.5 \pm 12.3)\end{array}$ & $\begin{array}{c}11.7 \pm 2.73 \\
(40.6 \pm 10.6)\end{array}$ & $\begin{array}{l}\text { ns } \\
\text { ns }\end{array}$ \\
\hline Respiration (assimilated) $^{\alpha}$ & $\begin{array}{c}2.81 \pm 0.35 \\
(18.8 \pm 7.17)\end{array}$ & $\begin{array}{c}3.27 \pm 0.70 \\
(11.3 \pm 4.17)\end{array}$ & $\begin{array}{c}\text { ns } \\
0.022\end{array}$ \\
\hline Incorporation (assimilated) & $\begin{array}{c}3.38 \pm 1.12 \\
(22.6 \pm 18.5)\end{array}$ & $\begin{array}{c}2.09 \pm 0.96 \\
(7.22 \pm 9.12)\end{array}$ & $\begin{array}{l}\text { ns } \\
\text { ns }\end{array}$ \\
\hline Total digestion & $\begin{array}{l}16.2 \pm 3.01 \\
(108 \pm 40.9)\end{array}$ & $\begin{array}{c}17.5 \pm 3.49 \\
(60.4 \pm 16.8)\end{array}$ & $\begin{array}{c}\text { ns } \\
0.010\end{array}$ \\
\hline Total assimilation & $\begin{array}{c}6.20 \pm 1.14 \\
(41.4 \pm 21.9)\end{array}$ & $\begin{array}{c}5.35 \pm 1.12 \\
(18.5 \pm 10.4)\end{array}$ & $\begin{array}{c}\text { ns } \\
0.018\end{array}$ \\
\hline November & $\mathrm{n}=8$ & $\mathrm{n}=8$ & \\
\hline Ingestion & $\begin{array}{c}100 \\
(305 \pm 73.5)\end{array}$ & $\begin{array}{c}100 \\
(187 \pm 57.7)\end{array}$ & $\overline{0.004}$ \\
\hline Defecation & $\begin{array}{l}70.2 \pm 7.30 \\
(214 \pm 75.1)\end{array}$ & $\begin{array}{l}61.0 \pm 7.23 \\
(114 \pm 43.1)\end{array}$ & $\begin{array}{c}\text { ns } \\
0.006\end{array}$ \\
\hline Solubilized in feces (digested) & $\begin{array}{c}6.16 \pm 0.74 \\
(18.8 \pm 7.29)\end{array}$ & $\begin{array}{c}5.11 \pm 0.40 \\
(9.55 \pm 2.38)\end{array}$ & $\begin{array}{c}\text { ns } \\
0.004\end{array}$ \\
\hline Solubilized in effluent (digested) & $\begin{array}{c}11.2 \pm 3.52 \\
(34.2 \pm 12.5)\end{array}$ & $\begin{array}{c}17.3 \pm 4.29 \\
(32.3 \pm 17.5)\end{array}$ & $\begin{array}{l}\text { ns } \\
\text { ns }\end{array}$ \\
\hline Respiration (assimilated) ${ }^{a}$ & $\begin{array}{c}6.13 \pm 1.20 \\
(18.7 \pm 3.37)\end{array}$ & $\begin{array}{c}9.63 \pm 1.08 \\
(18.0 \pm 4.86)\end{array}$ & $\begin{array}{c}0.011 \\
\text { ns }\end{array}$ \\
\hline Incorporation (assimilated) & $\begin{array}{c}12.4 \pm 1.75 \\
(37.7 \pm 14.0)\end{array}$ & $\begin{array}{c}12.2 \pm 3.36 \\
(22.8 \pm 14.1)\end{array}$ & $\begin{array}{l}\text { ns } \\
\text { ns }\end{array}$ \\
\hline Total digestion & $\begin{array}{l}35.7 \pm 5.68 \\
(109 \pm 21.7)\end{array}$ & $\begin{array}{c}44.2 \pm 6.70 \\
(82.6 \pm 25.4)\end{array}$ & $\begin{array}{c}\text { ns } \\
0.040\end{array}$ \\
\hline Total assimilation & $\begin{array}{c}18.5 \pm 2.17 \\
(56.4 \pm 14.3)\end{array}$ & $\begin{array}{c}21.8 \pm 4.07 \\
(40.7 \pm 16.6)\end{array}$ & $\begin{array}{l}\text { ns } \\
\text { ns }\end{array}$ \\
\hline
\end{tabular}


Between 52 and $86 \%$ of ingested $\left[{ }^{14} \mathrm{C}\right] \mathrm{PM}$ were defecated (Table 1), and greater than $95 \%$ of this defecated ${ }^{14} \mathrm{C}$ was produced before the sixteenth hour (fourth hour of second submergence period) of each $18 \mathrm{~h}$ experiment, regardless of diet type or time of year. The proportion of ingested ${ }^{14} \mathrm{C}$ that was soluble in the feces ('solubilized fecal ${ }^{14} \mathrm{C}$ ') ranged between 0.4 and $6.4 \%$. A greater proportion of ingested ${ }^{14} \mathrm{C}$ ( 7.9 to $17.4 \%$ ) was measured in the dissolved fraction of effluents ('solubilized effluent ${ }^{14} \mathrm{C}$ '). Solubilized ${ }^{14} \mathrm{C}$ in either feces or effluents was assumed to have been digested but not assimilated. Respiration accounted for 2.3 to $18.9 \%$ of the ${ }^{14} \mathrm{C}$-budget, and ${ }^{14} \mathrm{C}$ incorporated into tissues varied between 2.1 and $12.4 \%$ (Table 1). Digestion efficiencies varied considerably from 16\% (algal diet, August) to $53 \%$ (seston diet, February), and assimilation efficiencies showed similar seasonal differences from $5 \%$ (seston diet, August) to $31 \%$ (seston diet, February) (Table 1). This considerable variation in how $\left[{ }^{14} \mathrm{C}\right] \mathrm{PM}$ were utilized during the year was unlikely to be attributable to variation in characteristics of experimental diets. Among experiments, POM concentration ranged from only 2.4 to 3.9 $\mathrm{mg} \mathrm{l}^{-1}$ (38\% maximum variation), ${ }^{14} \mathrm{C}$-specific activity ranged from only $1.0 \times 10^{5}$ to $1.4 \times 10^{5} \mathrm{dpm}^{-1}(27 \%)$, and seawater flow rate ranged from only 3.6 to 4.5 l $(6$ h) $)^{-1}(19 \%)$.

In each of the 4 experiments, mussels fed $\left[{ }^{14} \mathrm{C}\right] \mathrm{PM}$ added to algae ingested significantly $(p<0.05)$ more $\left[{ }^{14} \mathrm{C}\right] \mathrm{PM}$ than mussels fed $\left[{ }^{14} \mathrm{C}\right] \mathrm{PM}$ added to natural seston (Table 1; Fig. 5). A 2-way ANOVA comparing ${ }^{14} \mathrm{C}$-ingestion among the main effects of diet type (algae or seston) and experimental date confirmed that ingestion differed significantly $(\mathrm{p}<0.0001)$ between

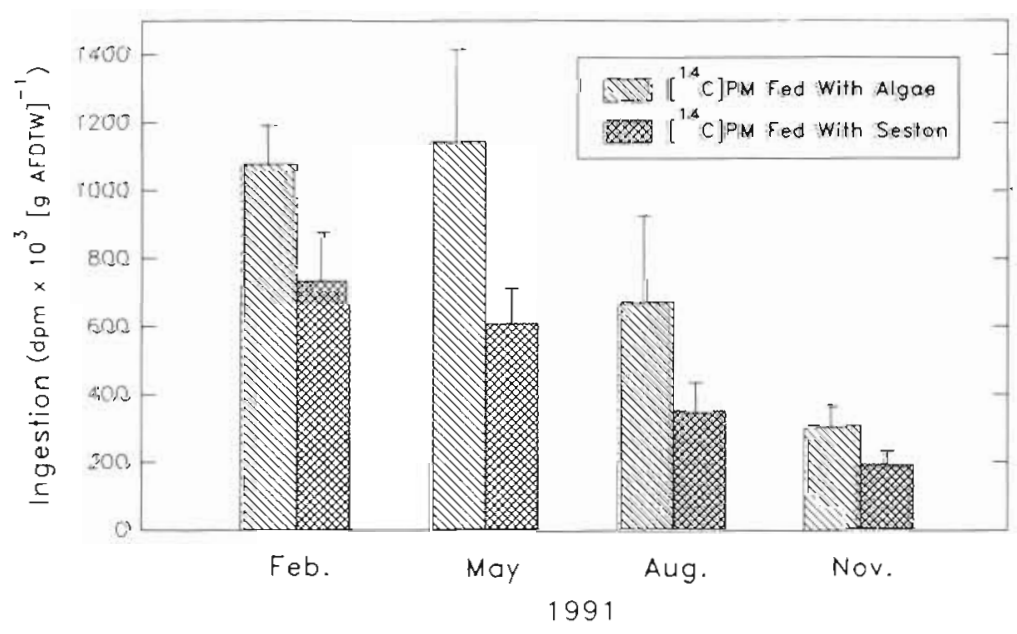

Fig. 5. Mytilus trossulus. Weight-specific ${ }^{14} \mathrm{C}$ ingestion $\left[\mathrm{dpm} \times 10^{3} \mathrm{~g}\right.$ ashfree dry tissue weight $\left.)^{-1}+95 \% \mathrm{CI}\right]$ of mussels fed on $\left[{ }^{14} \mathrm{Clprotein}\right.$ microcapsules in combination with either algae or seston during February, May, August and November 1991 the 2 types of diets, and there was a significant $(\mathrm{p}<$ 0.0001 ) seasonal effect in which a greater proportion of available $\left[{ }^{14} \mathrm{C}\right] \mathrm{PM}$ was ingested by mussels earlier (February, May) than later in the year (August, November) (Fig. 5). Even though mussels ingested $\left[{ }^{14} \mathrm{C} \mid \mathrm{PM}\right.$ at greater rates (per $6 \mathrm{~h}$ ) when fed with algae than with natural seston, the same seasonal pattern of variability in ingestion rates was observed regardless of diet type. There was no significant $(p>0.05)$ interaction between the two main effects of diet type and experiment date. Ingestion rates were equivalent to filtration rates in these experiments because mussels did not produce pseudofeces.

Mussels digested and assimilated a greater proportion of ingested ${ }^{14} \mathrm{C}$ during February and November than during May or August (Table 1, Fig. 6). In all experiments, digestion efficiencies for $\left[{ }^{14} \mathrm{C}\right] \mathrm{PM}$ were greater when capsules were fed with natural seston than when fed with algae (Fig. 6). Similarly, assimilation efficiencies for $\left[{ }^{14} \mathrm{C}\right] \mathrm{PM}$ were also greater when capsules were delivered with seston than with algae, except for the August experiment, when assimilation efficiencies were low (Fig. 6) and not significantly different between diets ( $t$-tests; Table 1). A 2-way ANOVA demonstrated that both diet type and experiment date significantly $(p<0.01$ ) affected digestion and assimilation efficiencies for $\left[{ }^{14} \mathrm{C}\right] \mathrm{PM}$.

To gain further insight into differences in the manner with which $\left[{ }^{14} \mathrm{C}\right] \mathrm{PM}$ were utilized by mussels, a ratio was calculated comparing the proportion of ingested ${ }^{14} \mathrm{C}$ that was respired (i.e. catabolized, $R$ ) to that incorporated into tissues $(T)$. ' $R / T$ ratios' were calculated for individual mussels, $\log _{10}$-transformed to adjust for unequal variances among groups, and compared between diet treatments and among experimental dates using a 2-way ANOVA. $R / T$ ratios varied significantly ( $\mathrm{p}$ $=0.0004$ ) among seasonal experiments; however, they did not differ significantly $(p>0.05)$ between dietary treat-ments. Therefore, $R / T$ ratios were pooled for both diets during each experiment and are presented in Fig. 7 along with $R / T$ ratios calculated from 3 similar ${ }^{14} \mathrm{C}$ feeding experiments conducted in December 1990 and April and June 1991 (see Kreeger 1992). $R / T$ ratios were not significantly $(p>0.05)$ different among the months of December, February, April, August, and November, and were not appreciably different from zero (Fig. 7), which indicated that respiration and tissue incorporation of assimilated protein were approximately equal at those times. In contrast, during May and June, $R / T$ ratios were significantly $(p<0.05)$ 


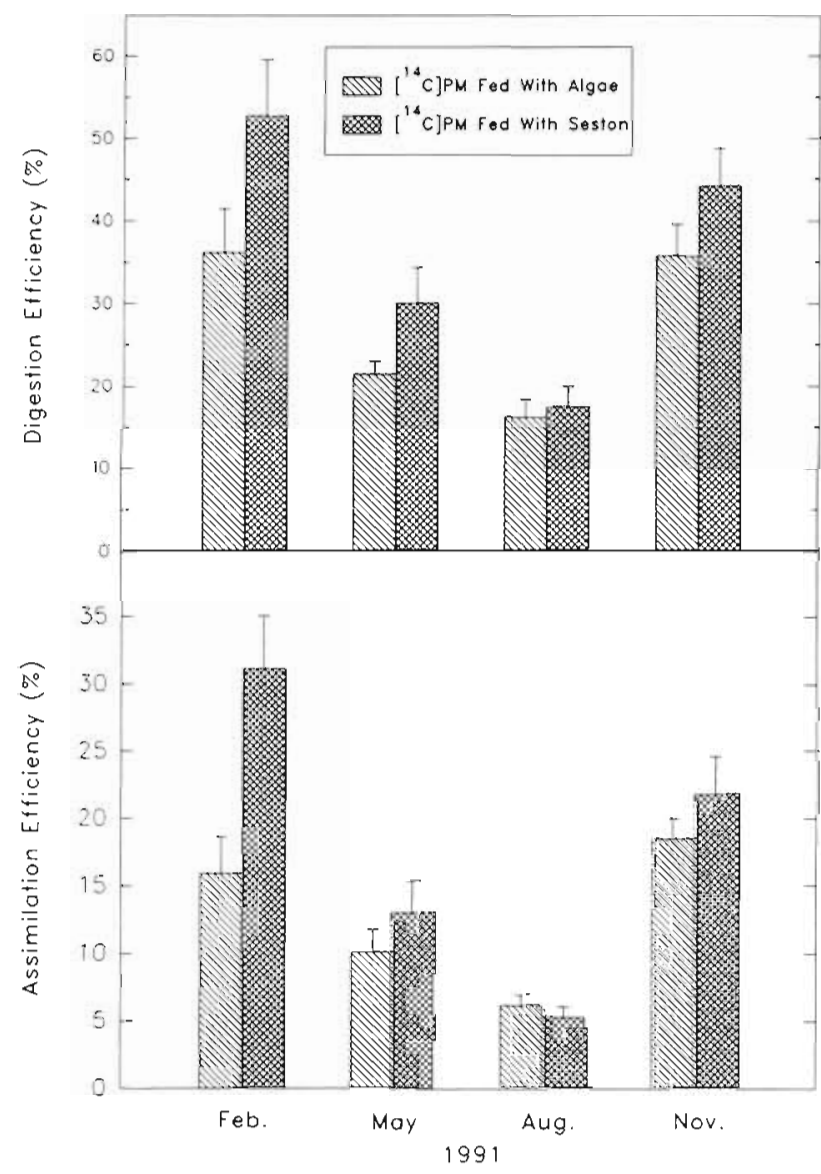

Fig. 6. Mytilus trossulus. (a) ${ }^{14} \mathrm{C}$-digestion efficiencies and (b) ${ }^{14} \mathrm{C}$-assimilation efficiencies $(+95 \% \mathrm{Cl}$ ) of mussels fed on $\left[{ }^{14} \mathrm{C}\right]$ protein microcapsules in combination with either algae or seston during February, May, August and November 1991

lower than zero (Fig. 7), which suggested that the majority of assimilated protein was being conserved from catabolism.

\section{Protein bioavailability in the seston}

The concentration of POM in seston from Yaquina Bay varied widely among bimonthly samples of 1991 and 1992 (Table 2). Although this variation was significant ( $p<0.0001$ ), there was no apparent seasonal cycle in the concentration of POM. For example, maximum and minimum POM concentrations were measured during January 1991 and 1992, respectively. In contrast, the concentration of 'bioavailable' protein, which was the proportion of POM liberated as dissolved protein by crystalline style extracts of mussels, was greatest during summer and lowest during winter (Table 2). The seasonal variability in the concentration of bioavailable protein was highly significant $(p=$ 0.0002 ).

The concentration of bioavailable protein in seston of Yaquina Bay (Table 2) was inversely proportional to the mussel's assimilation efficiency for $\left[{ }^{14} \mathrm{C}\right] \mathrm{PM}$ (Fig. 6), which might suggest that mussels were compensating for low natural protein availability during February and November by increasing their assimilation rate for dietary protein. In situ assimilation rates for seston protein (ARSP) were estimated by comparing concentrations of bioavailable protein in the seston to laboratory measurements of $\left[{ }^{14} \mathrm{C}\right] \mathrm{PM}$ utilization (when $\left[{ }^{14} \mathrm{C}\right] \mathrm{PM}$ were fed as a supplement to natural seston). Estimates of ARSP were made for each of the 4 seasonal experiments by dividing each mussel's ingestion rate for $\left[{ }^{14} \mathrm{C}\right] \mathrm{PM}$ [units $\left.=\mathrm{dpm} \mathrm{h}^{-1}(\mathrm{~g} \text { AFDTW })^{-1}\right]$ by the availability of $\left[{ }^{14} \mathrm{C}\right] \mathrm{PM}$ in the feeding system (seston diet treatment only; units $=\mathrm{dpm} \mathrm{I}^{-1}$ ) to calculate the mussel's particle clearance rate [units $=\mathrm{l} \mathrm{h}^{-1}$ (g AFDTW $)^{-1}$ ]. It was assumed that natural POM and $\left[{ }^{14} \mathrm{C} \mid \mathrm{PM}\right.$ would be cleared at the same rate, and so an estimate of the mussel's in situ ingestion rate of bioavailable seston protein [units $=\mathrm{mg} \mathrm{h}^{-1}(\mathrm{~g}$ AFDTW $)^{-1}$ ] was then made by multiplying the mussel's
Fig. 7. Mytilus trossulus. Seasonal changes in the ratio of ${ }^{14} \mathrm{C}$ respiration to ${ }^{14} \mathrm{C}$-incorporation ( $R / T$ ratio; $\pm 95 \% \mathrm{CI}$ ) in mussels fed $\left[{ }^{14} \mathrm{Clprotein}\right.$ microcapsules. Significant $(\alpha=0.05)$ differences among observations are indicated with different letters

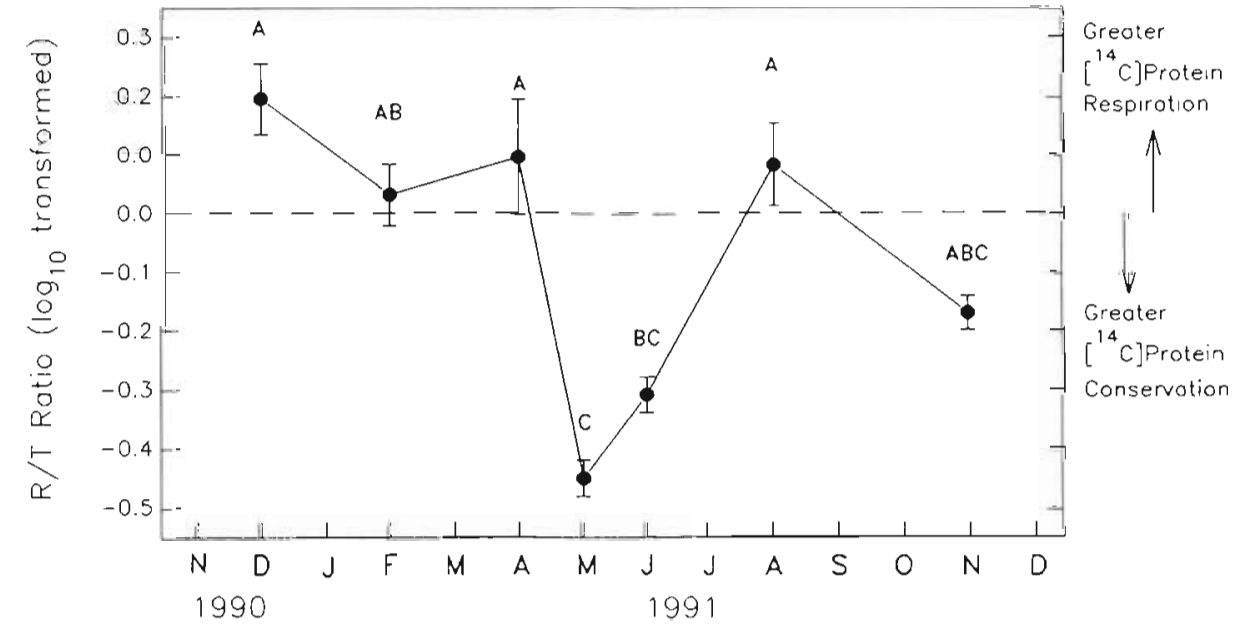


Table 2. Mean ( \pm SE) concentration of particulate organic material (POM) and bioavailable protein in seston of Yaquina Bay, Oregon, measured bimonthly between January 1991 and January 1992. Significant $(\alpha=0.05)$ differences among observations are indicated with different letters. nm: not measured

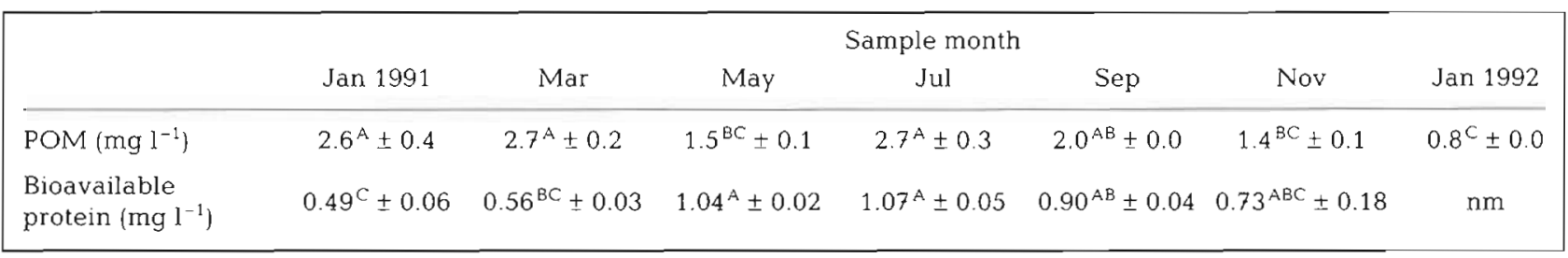

clearance rate $\left[\right.$ units $\left.=1 \mathrm{~h}^{-1}(\mathrm{~g} \text { AFDTW })^{-1}\right]$ by the in situ concentration of bioavailable seston protein (units = $\left.m g 1^{-1}\right)$. Finally, the ARSP [units $=m g h^{-1}(g$ AFDTW) ${ }^{-1}$ ] was calculated by multiplying the estimated ingestion rate of bioavailable seston protein [units $\left.=\mathrm{mg} \mathrm{h}^{-1}(\mathrm{~g} \text { AFDTW })^{-1}\right]$ by the assimilation efficiency for seston protein (units $=\%$ ), which was assumed to be equivalent to the measured assimilation efficiency for $\left[{ }^{14} \mathrm{C}\right] \mathrm{PM}$. This latter assumption was not tested experimentally but is supported by the observation that natural seston is typically assimilated by mussels with efficiencies (e.g. 35\%; Bayne \& Widdows 1978, Bayne \& Newell 1983) that are similar to those for $\left[{ }^{14} \mathrm{C}\right] \mathrm{PM}(<40 \%$; Kreeger 1992). Estimates of ARSP therefore integrated several parameters which varied seasonally, including concentrations of bioavailable protein in the seston (Table 2), mussel ingestion rates for $\left[{ }^{14} \mathrm{C}\right] P M$ (Table 1), and assimilation efficiencies for $\left[{ }^{14} \mathrm{C}\right.$.PM (Table 1).

The ARSP of Mytilus trossulus in Yaquina Bay was estimated to vary between 20 and $180 \mu \mathrm{g}$ protein $\mathrm{h}^{-1}$ (g AFDTW) ${ }^{-1}$ (Fig. 8), and the seasonal pattern of estimated ARSP was similar to that shown previously for

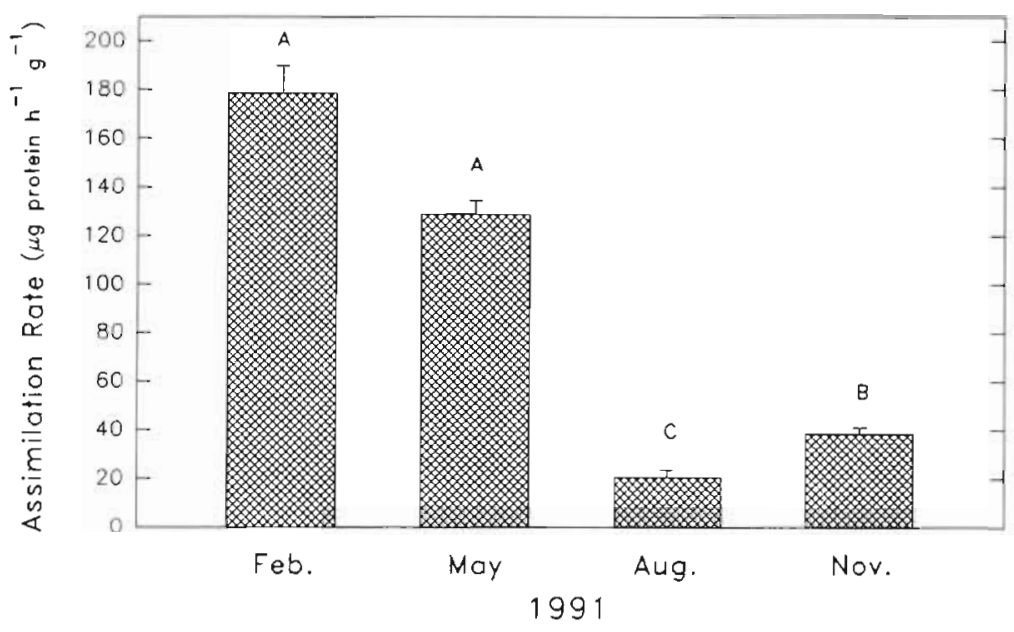

Fig. 8. Mytilus trossulus. Estimated assimilation rates (+95\% CI) of bioavailable protein by mussels in Yaquina Bay, Oregon, during February, May, August and November 1991. Significant $(\alpha=0.05)$ differences among observations are indicated with different letters the assimilation efficiencies for $\left[{ }^{14} \mathrm{C}\right] \mathrm{PM}$ (Fig. 6). This result suggests that mussels were in fact assimilating significantly $(p<0.05)$ more protein during the late winter and spring than during the summer and fall (Fig. 8), and were not simply compensating for variation in protein abundance in order to maintain a constant protein assimilation rate.

Estimated ARSP's were also compared to rates of ammonia nitrogen excretion to estimate whether mussels in Yaquina Bay remained in positive nitrogen balance at all times of the year. The ARSP was divided by 5.85 (Gnaiger \& Bitterlich 1984 ) to estimate the rate of protein nitrogen assimilated in situ by mussels during winter (February), spring (May), summer (August) and fall (November), which was 30.5, 22.1, 3.54, and $6.58 \mu \mathrm{g} \mathrm{N} \mathrm{h}{ }^{-1}$ (g AFDTW $)^{-1}$, respectively. Rates of ammonia nitrogen excretion, averaged for the winter (January to March), spring (April to June), summer (July-September), and fall (October-December) were 2.97, 1.71, 4.07, and $1.52 \mu \mathrm{g} \mathrm{N} \mathrm{h}^{-1}$ (g AFDTW) $^{-1}$, respectively. Therefore, mussels potentially met their metabolic nitrogen requirements by utilization of bioavailable seston protein during the winter, spring and fall; however, during the summer, the rate of loss of metabolic nitrogen was greater than the rate of protein nitrogen assimilation. Net nitrogen balance of Mytilus trossulus was estimated to be $+27.5,+20.4,-0.5$, and $+5.1 \mu \mathrm{g} \mathrm{N} \mathrm{h}{ }^{-1}(\mathrm{~g}$ AFDTW $)^{-1}$ during the winter, spring, summer and fall, respectively.

\section{DISCUSSION}

Utilization of dietary protein by Mytilus trossulus significantly varied seasonally as shown by changes in the mussels' ingestion rates, digestion efficiencies and assimilation efficiencies for defined, ${ }^{14} \mathrm{C}$ labeled protein microcapsules $\left(\left[{ }^{14} \mathrm{C}\right] \mathrm{PM}\right)$. Regardless of whether $\left[{ }^{14} \mathrm{C}\right] P M$ were added to a diet of algae or natural seston, mussels ingested $\left[{ }^{14} \mathrm{C}\right.$ PPM at greater rates 
and assimilated $\left[{ }^{14} \mathrm{C}\right] \mathrm{PM}$ with greater efficiencies during the late winter and spring than at other times of the year. Integration of ingestion rates with assimilation efficiencies suggested that assimilation rates of $\left[{ }^{14} \mathrm{C}\right] \mathrm{PM}$ were more than 7 times greater during February than during August. $\left[{ }^{14} \mathrm{C}\right] \mathrm{PM}$ were constant in composition and ration among all feeding experiments and only comprised a minor fraction of the total dry diet weight $(<25 \%)$; therefore, they were found to be useful 'probes' for comparing the mussels' ability to assimilate protein under various dietary conditions and at different times of the year.

Seasonal differences in food utilization by suspension-feeders have rarely been studied. Bayne \& Widdows (1978) reported that Mytilus edulis cleared natural particulate organic material at greatest rates in spring and early summer and assimilated particulate organic material with greatest efficiency during summer. Hawkins et al. (1985) reported that absorption efficiencies for dietary energy in $M$. edulis varied seasonally, but they suggested that rates of energy acquisition were 'time-optimized', with short-term deficiencies in energy intake being met by reliance on internal energy reserves. Absorption rates for dietary protein by $M$. edulis have also been estimated to vary seasonally (Bayne \& Widdows 1978, Widdows 1978). For example, Bayne \& Widdows (1978) estimated that mussels in the Lynher estuary, southwest England, absorbed protein at greatest rates during July, which coincided with or just preceded greatest reproductive condition in the mussels, whereas lowest protein absorption rates occurred following spawning in the fall. Hawkins \& Bayne (1985) reported that ingestion rates, absorption efficiencies, and metabolic requirements for nitrogen in $M$. edulis varied during the year in such a way that net nitrogen balance was negative in March, but highly positive in June and October. This finding suggested to Hawkins \& Bayne (1985) that mussels were relying on internal reserves of nitrogen during March, and thus were 'time-optimizing' nitrogen balance, rather than simply increasing their rate of nitrogen uptake to compensate for the deficiency. Hawkins (1985) further examined the mussels' utilization of endogenous amino-nitrogen by delivering ${ }^{15} \mathrm{~N}$ labeled microalgae to $M$. edulis and using ${ }^{15} \mathrm{~N}$ as a tracer for amino-nitrogen. This allowed Hawkins to quantify the ${ }^{15} \mathrm{~N}$-budget and rate of whole body protein turnover (WBPT) at different times of the year and under different experimental conditions. Mussels were found to have an efficient system for recycling internal nitrogen, and importantly, the rate of WBPT varied seasonally and among mussels differing in physiological condition.

In this study, Mytilus trossulus collected from Yaquina Bay, assimilated dietary protein, as indicated by incorporation of ${ }^{14} \mathrm{C}$ from $\left[{ }^{14} \mathrm{C}\right] \mathrm{PM}$, at widely varying rates during the year, which could have been a compensatory mechanism with which mussels adjusted to long-term (e.g. seasonal) deficiencies between the availability of dietary protein and the mussels' nutritional requirements for amino-nitrogen. Greatest protein assimilation rates were measured during spring when concentrations of bioavailable protein in seston of Yaquina Bay were low and gamete maturation was accelerating in mussels. As reported by Hawkins \& Bayne (1991) for $M$. edulis, $M$. trossulus could have compensated for periods of reduced availability of seston protein by adjusting their rate of WBPT as well as by increasing their rate of assimilation of exogenous protein. The rate of WBPT was not measured in this study, however, and the relative utilization of exogenous protein versus endogenous protein reserves in satisfying the mussels' requirements for amino-nitrogen needs to be addressed. The strategy for protein balance of $M$. edulis in southwest England (Hawkins \& Bayne 1991) may also be quite different from that of $M$. trossulus in Yaquina Bay.

The assimilation efficiency of bivalves can be influenced by many physiological factors, including enzymatic digestive activity, gut residence time, gut capacity, and digestive synchrony (Bayne \& Newell 1983, Bayne et al. 1984, 1988, Hawkins et al. 1990). Seasonal variation in these factors has not been previously correlated with seasonal patterns of food availability, food digestion and assimilation, or bivalve physiology, although Eble (1966) observed that the digestive diverticula of oysters (Crassostrea virginica) contained a more diverse suite of digestive enzymes during times of the year when the animals were feeding most actively. No significant differences were observed among experiments in this study in the gut residence time of Mytilus trossulus; however, during late winter and spring, proteolytic activity associated with the crystalline style and diverticula was significantly greater than during the summer and fall, which suggests that assimilation efficiencies for [ $\left.{ }^{14} \mathrm{C}\right] \mathrm{PM}$ may have resulted in part from seasonal variation in gut enzymatic activity.

In all experiments, mussels ingested $\left[{ }^{14} \mathrm{C}\right] \mathrm{PM}$ at a significantly greater rate when capsules were delivered as a supplement to microalgae than natural seston. This is not surprising because previous workers (Bayne et al. 1984, Ward \& Targett 1989, Ward et al. 1992) have reported that the presence of microalgae and dissolved metabolites from microalgae can evoke changes (both increases and decreases) in feeding activity by bivalves. In this study, concentrations of algae and their metabolites were probably greater in algal diets than in natural seston, which could have elicited higher ingestion rates for $\left[{ }^{14} \mathrm{C}\right] \mathrm{PM}$ when fed 
with algae than with seston. In contrast, digestion and assimilation efficiencies of $\left[{ }^{14} \mathrm{C}\right] \mathrm{PM}$ were significantly greater when capsules were delivered with seston than with algae. The reason for this difference is unclear. Although gut residence time has been directly related to assimilation efficiency (Calow 1975, Bayne et al. 1984), gut residence time did not appear to differ between mussels fed algal or seston background diets. No bacterial ${ }^{14} \mathrm{C}$-respiration was detected in beakers containing either experimental diet; therefore, bacteria associated with natural seston did not indirectly facilitate utilization of ${ }^{14} \mathrm{CJPM}$ by mediating the flow of ${ }^{14} \mathrm{C}$ from capsules to the mussel. However, if seston bacteria were ingested and digested by mussels, it is possible that digestive enzymes liberated from bacterial cells could have aided in capsule breakdown in the mussel's gut. Furthermore, inorganic seston particles could have facilitated physical breakdown of $\left[{ }^{14} \mathrm{C}\right] \mathrm{PM}$ (Kiørboe et al. 1980, Urban \& Langdon 1984 , Bayne et al. 1987). An alternative explanation is that the digestive activity of mussels acclimated to a diet of natural seston (low nutritional quality) could have been greater than the digestive activity of mussels acclimated to an algal diet (high nutritional quality). The effect of acclimation on digestive activity was not specifically examined in this study.

Differences in the strategy with which mussels utilized $\left[{ }^{14} \mathrm{C}\right] \mathrm{PM}$ from different 'background' diets were somewhat serendipitous findings, but are interesting in light of optimal feeding models devised for invertebrates (Taghon 1981, Penry \& Jumars 1987, 1990, Penry 1989, Dade et al. 1990, Willows 1992). Taghon (1981) predicted that an optimal response for a deposit-feeder given a better quality diet would be to increase its ingestion rate, and Taghon \& Jumars (1984) later reported that ingestion rates of depositfeeding polychaetes increased with dietary protein content. Regulation of ingestion rate would seem to be a better strategy for optimizing energy balance than regulation of assimilation efficiency because Widdows \& Hawkins (1989) reported that the metabolic costs of feeding and moving food through the gut of Mytilus edulis were much lower $(<3 \%$ of metabolic energy expenditures) compared to costs associated with the digestion and absorption of food (17\% of metabolic energy expenditures). In this study mussels both ingested $\left[{ }^{14} \mathrm{C} \mid \mathrm{PM}\right.$ at greater rates and assimilated $\left[{ }^{14} \mathrm{C}\right] \mathrm{PM}$ with lower efficiencies when capsules were added to a high quality diet (algae) than when fed with a low quality diet (seston), which could have been an 'optimal' response, with lower energy costs associated with digestion and absorption of microalgae. This resulted in actual weight-specific assimilation rates for $\left[{ }^{14} \mathrm{C}\right] \mathrm{PM}$ that were not significantly different between mussels fed the 2 different diets. Other researchers have also reported reduced assimilation efficiencies (not specifically of protein) for bivalves fed algal diets compared to those fed low-quality, natural diets (Bayne et al. 1984, Deslous-Paoli et al. 1990), and bivalve ingestion rates have also been directly associated with food quality (Bayne \& Newell 1983, Bayne et al. 1984, 1987). These findings suggest that an optimal 'foraging' model for suspension-feeding bivalves should not neglect aspects of food quality and should be based on maximizing overall rates of assimilation

Regardless of whether the 'background' diet was algae or natural seston, mussels ingested $\left[{ }^{14} \mathrm{C}\right] \mathrm{PM}$ at higher rates and assimilated $\left[{ }^{14} \mathrm{C}\right] P M$ with greater efficiencies during the winter and spring, which resulted in higher net assimilation rates during late winter and spring than at other times of the year. Even though the algal/capsule diet was constant in composition among experiments, assimilation efficiencies for $\left[{ }^{14} \mathrm{C}\right] \mathrm{PM}$ still varied according to season. These results suggest that the overall seasonal pattern in protein utilization was primarily dependent on the mussels ${ }^{\prime}$ physiological condition and not on diet composition at the time of the experiment.

The concentration of bioavailable protein in seston of Yaquina Bay was significantly greater during summer than winter, but the total range in bioavailable protein concentration was not very large $\left(0.5\right.$ to $\left.1.1 \mathrm{mg} \mathrm{l}^{-1}\right)$, and was similar to the annual range of protein concentrations $\left(0.4\right.$ to $\left.0.6 \mathrm{mg} \mathrm{l}^{-1}\right)$ reported for seston in the Lynher estuary, England (Bayne \& Widdows 1978). To obtain an integrative estimate of actual protein assimilation rates for mussels in situ, ambient concentrations of bioavailable protein were compared to ingestion rates and assimilation efficiencies of mussels fed $\left[{ }^{14} \mathrm{C}\right] \mathrm{PM}$ with natural seston. Even after consideration of seasonal variation in the abundance of bioavailable protein, the resulting overall assimilation rates still varied significantly. This result again indicates that the mussel's physiological condition was of greater importance than the composition of its diet, particularly the availability of dietary protein, in determining the mussel's seasonal pattern of protein assimilation.

The physiological condition of Mytilus trossulus in Yaquina Bay was monitored to provide insight into possible reasons for the observed seasonal differences in protein uptake. Natural populations of $M$. trossulus in the Pacific Northwest are considered to be 'dribble' or continuous spawners in which spawning may occur at any time of the year, but generally is greatest in spring and summer (Emmett et al. 1987). Indeed, at all times of the year, some mussels in Yaquina Bay contained developing or ripe gametes; however, during May nearly every sampled mussel was sexually 
mature, demonstrating a distinct springtime peak in reproductive activity. Both the proportion of mantle tissue occupied by developing or ripe gametes and the proportion of the mussel's dry body weight comprised of gametes were significantly greater during May than at other times of the year. Associated with this reproductive cycle, mussels showed the classical patterns in tissue biochemical composition that have been attributed to reproductive cycles of other bivalves (for review, see Gabbott 1983). Bivalves are thought to accumulate energy and nutrient reserves, primarily as glycogen, during a conditioning period preceding gametogenesis. These energy stores are then used as an energy reserve for overwintering and gametogenesis. At the onset of gametogenesis, remaining carbohydrate reserves are either catabolized or converted into lipids, which are sequestered in the developing eggs. Indeed, carbohydrate content and overall condition index of $M$. trossulus gradually increased during the summer and fall, and dropped rapidly between November and January. Tissue lipid content was greatest during April and May, but was not significantly different from other times of the year. Given that the peak in spawning occurred between May and June, this would suggest that gametogenesis spanned the period between January and May.

Very little is known about the importance of protein during conditioning and gametogenesis (for review, see Gabbott 1983). Despite reports (Gabbott 1983, Gabbott \& Peek 1991) that greater than $50 \%$ of the dry weight of the bivalve egg is comprised of protein, the protein content of the tissues of Mytilus edulis has generally been reported to be greatest during nonreproductive periods. This is because $M$. edulis typically spawns at the peak in condition (Hawkins et al. 1985). In the present study, however, $M$. trossulus spawned when condition index was lowest. Tissue protein content was significantly greater during gametogenesis (March to May) than during the rest of the year, and it is likely that much of this extra tissue protein was directly associated with gametes. Perhaps $M$. trossulus in the northwestern U.S. reproduce when in sub-optimal condition during early spring so as to produce larvae prior to spring and early summer phytoplankton blooms.

Bayne \& Thompson (1970) examined seasonal variation in $\mathrm{O} / \mathrm{N}$ ratios of Mytilus edulis, which led them to suggest that carbohydrate served as the primary energy substrate during late winter and early spring when body protein and lipid contents were increasing. However, in later studies, Bayne (1973a, b) and Bayne \& Widdows (1978) reported that during gametogenesis, protein served as the primary substrate for catabolism. Similarly, Barber \& Blake (1985) reported that $\mathrm{O} / \mathrm{N}$ ratios of scallops Argopecten irradians con- centricus were lowest during gametogenesis, again suggesting that protein was being used as a source of energy during peak reproduction. In this study, $\mathrm{O} / \mathrm{N}$ ratios measured for $M$. trossulus were greater than 20 during the March to July period, which indicated preferential catabolism of carbohydrate. Most importantly, the mean $\mathrm{O} / \mathrm{N}$ ratio during May was greater than 50, which suggested that dietary protein was conserved from metabolism at a time when mussels contained the greatest proportion of developing or ripe gametes (just prior to spawning). Catabolism became protein-based only during the fall and winter when carbohydrates were accumulated as an energy reserve. Therefore, reports on the relative catabolism of carbohydrate or protein during gametogenesis are equivocal, which could result from interspecific differences, or also intraspecific variation in physiological condition or nutritional status (e.g. Gabbott \& Bayne 1973, Kreeger \& Langdon 1993).

A second indicator of the relative catabolism or conservation of dietary protein was derived using data pooled from $7{ }^{14} \mathrm{C}$-feeding experiments $(3$ from Kreeger 1992), whereby ${ }^{14} \mathrm{C}$ respiration by mussels $(R)$ was expressed relative to ${ }^{14} \mathrm{C}$ incorporated into mussel tissues $(T)$. After log-transformation, positive values of this ' $R / T$ ratio' indicated a greater portion of ingested $\left[{ }^{14} \mathrm{C}\right] \mathrm{PM}$ were catabolized than incorporated, whereas negative values reflected greater tissue uptake and relatively lower protein catabolism. Positive $R / T$ ratios were measured at all times of the year, except during April and May, when $R / T$ ratios were significantly negative. As indicated by the mussels' $\mathrm{O} / \mathrm{N}$ ratios, these results suggest that protein was being conserved from metabolic breakdown during the final stages of gametogenesis.

In summary, Mytilus trossulus collected from Yaquina Bay, utilized dietary protein with different efficiencies during the year. This variability, assessed by conducting in vivo feeding experiments with $\left[{ }^{14} \mathrm{C}\right.$ PM, appeared to be more related to seasonal changes in the digestive physiology and reproductive condition of mussels than to differences in the composition of experimental diets. Based on the observations reported here, there appeared to be 3 general phases in the annual protein budget of these mussels. The first phase, which occurred during gametogenesis between December and April, was characterized by a high efficiency of protein assimilation, increased tissue protein content, and increasing metabolic conservation of dietary protein compared to dietary lipid and carbohydrate. The second phase occurred during May and June and was characterized by a rapid decrease in protein assimilation efficiency and tissue protein content following spawning, but metabolic conservation of dietary protein remained high. The third phase began 
after spawning (e.g. June-July) and continued until late fall (e.g. November-December) and was characterized by a low assimilation efficiency for dietary protein, increasing tissue carbohydrate content, and greater catabolism of assimilated protein. These results suggest that during the latter stages of gametogenesis, $M$. trossulus may have a greater dietary requirement for protein than when mussels are not reproductively active. Mussels appear to meet this extra demand for exogenous protein during gametogenesis by increasing rates and efficiencies of protein digestion and assimilation and by conserving assimilated protein from catabolic processes.

Acknowledgements. I thank C. J. Langdon for extensive advice and assistance as well as for comments on this manuscript. Additional comments on this paper were provided by A. J. S. Hawkins, B. L. Bayne and K. Y. Kreeger. This research was supported by Oregon Sea Grant, National Oceanographic and Atmospheric Association, Office of Sea Grant, Department of Commerce, Grant No. NA 85AA-D-SG095 under Project R/AQ-56 to C. J. Langdon. Additional support was provided to D.A.K. by a Graduate School Fellowship from Oregon State University, a Brucefield-Reynolds Scholarship from the Hatfield Marine Science Center, and a Mastin Grant from the Department of Fisheries and Wildlife, Oregon State University

\section{LITERATURE CITED}

Asmus, R. M., Asmus, H. (1991). Mussel beds: limiting or promoting phytoplankton? J. exp. mar. Biol. Ecol. 148: $215-232$

Barber, B. J., Blake, N. J. (1985). Substrate catabolism related to reproduction in the bay scallop Argopecten irradians concentricus, as determined by $\mathrm{O} / \mathrm{N}$ and $\mathrm{RQ}$ physiological indexes. Mar. Biol. 87: 13-18

Bayne, B. L. (1973a). Aspects of the metabolism of Mytilus edulis during starvation. Neth. J. Sea Res. 7: 399-410

Bayne, B. L. (1973b). Physiological changes in Mytilus edulis L. induced by temperature and nutritive stress. J. mar biol. Ass. U.K. 53: 39-58

Bayne, B. L., Hawkins, A. J. S., Navarro, E. (1987). Feeding and digestion by the mussel Mytilus edulis L. (Bivalvia: Mollusca) in mixtures of silt and algal cells at low concentrations. J. exp. mar. Biol. Ecol. 111: 1-22

Bayne, B. L., Hawkins, A. J. S., Navarro, E. (1988). Feeding and digestion in suspension-feeding bivalve molluscs: the relevance of physiological compensations. Am. Zool. 28: $147-159$

Bayne, B. L., Holland, D. L., Moore, M. N., Lowe, D. M. Widdows, J. (1978). Further studies on the effects of stress in the adult on the eggs of Mytilus edulis. J. mar. biol. Ass. U.K. 58: 825-841

Bayne, B. L., Klumpp, D. W., Clarke, K. R. (1984). Aspects of feeding, including estimates of gut residence time, in three mytilid species (Bivalvia, Mollusca) at two contrasting sites in the Cape Peninsula, South Africa. Oecologia 64: $26-33$

Bayne, B. L., Newell, R. C. (1983). Physiological energetics of marine Mollusca. In: Saleuddin, A. S. M., Wilbur, K. M. (eds.) The Mollusca, Vol. 4. Academic Press, New York, p. $407-515$
Bayne, B. L., Thompson, R. J. (1970). Some physiological consequences of keeping Mytilus edulis in the laboratory. Helgoländer wiss. Meeresunters. 20: 526-552

Bayne, B. L., Widdows, J. (1978). The physiological ecology of two populations of Mytilus edulis L. Oecologia 37: $137-162$

Berg, J, A., Newell, R. I. E. (1986). Temporal and spatial variations in the composition of seston available to the suspension feeder Crassostrea virginica. Estuar. coast. Shelf. Sci. 23: 375-386

Brock, V., Kennedy, V. S., Brock, A. (1986). Temperature dependency of carbohydrase activity in the hepatopancreas of thirteen estuarine and coastal bivalve species from the North American east coast. J. exp. mar. Biol. Ecol. 103: $87-101$

Burt, W. V. (1955). Distribution of suspended materials in Chesapeake Bay. J. mar. Res. 14: 47-62

Calow, P. (1975). Defaecation strategies of two freshwater gastropods, Ancylus fluviatilis Mull. and Planorbis contortus Linn. (Pulmonata) with a comparison of field and laboratory estimates of food absorption rate. Oecologia 20: $51-63$

Chanut, J. P., Poulet, S. A. (1982). Short-term vanability of the size spectra of suspended particles in a rapidly changing environment. Estuar. coast. Shelf Sci. 15: 497-513

Crosby, M. P., Gale, L. D. (1990). A review and evaluation of bivalve condition index methodologies with a suggested standard method. J. Shellfish Res. 9: 233-238

Dade, W. B., Jumars, P. A., Penry, D. L. (1990). Supply-side optimization: maximizing absorptive rates. In: Hughes, R. N. (ed.) Behavioural mechanisms of food selection. Springer-Verlag, Berlin, p. 531-555

Deslous-Paoli, J. M., Boromthanarat, S., Heral, M., Boromthanarat, W., Razat, D. (1990). Energy budget of a Mytilus edulis L. population during its first year on bouchots in the bay of Marennes-Oleron. Aquaculture 91: 49-63

Dubois, M., Gilles, K. A., Hamilton, J. K., Rebers, P. A., Smith, F. (1956). A colorimetric method for the determination of sugars and related substances. Analyt. Chem. 28: 350-356

Eble, A. F. (1966). Some observations on the seasonal distribution of selected enzymes in the American oyster as revealed by enzyme histochemistry. Proc. natl Shellfish Ass. 56: $37-42$

Emmett, B., Thompson, K., Popham, J. D. (1987). The reproductive and energy storage cycles of two populations of Mytilus edulis (Linne) from British Columbia. J. Shellfish Res. 6: 29-36

Folch, J., Lees, M., Sloane-Stanley, G. H. (1957). A simple method for the isolation and purification of total lipids from animal tissue. J. biol. Chem. 226: 497-509

Gabbott, P. A. (1976). Energy metabolism. In: Bayne, B. L. (ed.) Marine mussels. Cambridge University Press, New York, p. 293-355

Gabbott, P. A. (1983). Developmental and seasonal metabolic activities in marine molluscs. In: Hochachka, P. W. (ed.) The Mollusca, Vol. 2. Academic Press, New York, p. $165-217$

Gabbott, P. A., Bayne, B. L. (1973). Biochemical effects of temperature and nutritive stress on Mytilus edulis $\mathrm{L}$. J. mar. biol. Ass. U.K. 53: 269-286

Gabbott, P. A., Peek, K. (1991). Cellular biochemistry of the mantle tissue of the mussel Mytilus edulis L. Aquaculture 94: 165-176

Galvao, H. M. Fritz, A. T. (1991). Microbial trophodynamics in a salt-marsh. Mar. microb. Food Webs 5: 13-26

Gnaiger, E., Bitterlich, G. (1984). Proximate biochemical composition and caloric content calculated from elemental 
CHN analysis: a stoichiometric concept. Oecologia 62 289-298

Hawkins, A. J. S. (1985). Relationships between the synthesis and breakdown of protein, dietary absorption and turnovers of nitrogen and carbon in the blue mussel, Mytilus edulis L. Oecologia 66: 42-49

Hawkins, A. J. S., Bayne, B. L. (1985). Seasonal variation in the relative utilization of carbon and nitrogen by the mussel Mytilus edulis: budgets, conversion efficiencies and maintenance requirements. Mar. Ecol. Prog. Ser. 25: $181-188$

Hawkins, A. J. S., Bayne, B. L. (1991). Nutrition of marine mussels: factors influencing the relative utilizations of protein and energy. Aquaculture 94: 177-196

Hawkins, A. J. S., Bayne, B. L., Clarke, K. R. (1983). Coordinated rhythms of digestion, absorption and excretion in Mytilus edulis (Bivalvia: Mollusca). Mar. Biol. 74: 41-48

Hawkins, A. J. S., Navarro, E., Iglesias, J. I. P. (1990). Comparative allometries of gut-passage time, gut content and metabolic faecal loss in Mytilus edulis and Cerastoderma edule. Mar. Biol. 105: 197-204

Hawkins, A. J. S., Salkeld, P. N., Bayne, B. L., Gnaiger, E., Lowe, D. M. (1985). Feeding and resource allocation in the mussel Mytilus edulis: evidence for time-averaged optimization. Mar. Ecol. Prog. Ser. 20: 273-287

Hicks, R. E., Lee, C., Marinucci, A. C. (1991). Loss and recycling of amino acids and protein from smooth cordgrass (Spartina alterniflora) litter. Estuaries 14: 430-439

Kiørboe, T., Mohlenberg, F., Nøhr, O. (1980). Feeding, particle selection and carbon absorption in Mytilus edulis in different mixtures of algae and resuspended bottom material. Ophelia 19: 193-205

Kreeger, D. A. (1992). Utilization of dietary protein by the mussel, Mytilus edulis trossulus. Ph.D. dissertation, Oregon State University, Corvallis

Kreeger, D. A., Langdon, C. J. (1993). Effect of dietary protein content on growth of juvenile mussels, Mytilus trossulus (Gould 1859). Biol. Bull. (in press)

Kreeger, D. A., Langdon, C. J., Newell, R. I. E. (1988). Utilization of refractory cellulosic carbon derived from Spartina alterniflora by the ribbed mussel Geukensia demissa. Mar. Ecol. Prog. Ser. 42: 171-179

Kreeger, D. A., Newell, R. I. E., Langdon, C. J. (1990). Effect of tidal exposure on utilization of dietary lignocellulose by the ribbed mussel Geukensia demissa (Dillwyn) (Mollusca: Bivalvia). J. exp. mar. Biol. Ecol. 144: 85-100

Langdon, C. J., Levine, D. M., Jones, D. A. (1985). Microparticulate feeds for marine suspension-feeders. J. Microencapsulation 2: 1-11

Langdon, C. J., Newell, R. I. E. (1990). Utilization of detritus and bacteria as food sources by two bivalve suspensionfeeders, the oyster Crassostrea virginica and the mussel Geukensia demissa. Mar. Ecol. Prog. Ser. 58: 299-310

Langton, R. W. (1975). Synchrony in the digestive diverticula of Mytilus edulis L. J. mar. biol. Ass. U.K. 55: 221-229

Langton, R. W. (1977). Digestive rhythms in the mussel Mytilus edulis. Mar. Biol. 41: 53-58

Lowe, D. M., Moore, M. N., Bayne, B. L. (1982). Aspects of gametogenesis in the marine mussel Mytilus edulis L. J. mar. biol. Ass. U.K. 62: 133-145

Lowry, O. H., Rosebrough, N. J., Farr, A. L., Randall, R. J (1951). Protein measurement with the folin phenol reagent. J. biol. Chem. 193: 265-275

Manahan, D. T., Wright, S. H., Stephens, G. C., Rice, M. A (1982). Transport of dissolved amino acids by the mussel Mytilus edulis: demonstration of net uptake from natural seawater. Science 215: 1253-1255
Mathers, N. F. (1974). Digestion and $\mathrm{pH}$ variation in two species of oysters. Proc malacol. Soc. Lond. 41: 37-40

Mayzaud, P., Chanut, J. P., Ackman, R. G. (1989). Seasonal changes of the biochemical composition of marine particulate matter with special reference to fatty acids and sterols. Mar. Ecol. Prog. Ser. 56: 189-204

Morton, B. (1977). The tidal rhythm of feeding and digestion in the Pacific oyster, Crassostrea gigas (Thunberg). J. exp mar. Biol. Ecol. 26: 135-151

Morton, B. (1983). Feeding and digestion in Bivalvia. In: Saleuddin, A. S. M., Wilbur, K. M. (eds.) The Mollusca, Vol. 5, Part 2. Academic Press, New York, p. 65-147

Newell, R. I. E., Hilbish, T J., Koehn, R. K., Newell, C. J. (1982). Temporal variation in the reproductive cycle of Mytilus edulis L. (Bivalvia, Mytilidae) from localities on the east coast of the United States. Biol. Bull. 162: 299-310

Penry, D. L. (1989). Tests of kinetic models for deposit-feeders' guts: patterns of sediment processing by Parastichopus californicus (Stimpson) (Holothuroidea) and Amphicteis scaphobranchiata Moore (Polychaeta). J. exp. mar. Biol. Ecol. 128: 127-146

Penry, D. L., Jumars, P. A. (1987). Modeling animal guts as chemical reactors. Am. Nat. 129: 69-96

Penry, D. L., Jumars, P. A. (1990). Gut architecture, digestive constraints and feeding ecology of deposit-feeding and carnivorous polychaetes. Oecologia 82: 1-11

Reid, R. G. B. (1982). Aspects of bivalve feeding and digestion relevant to aquaculture nutrition. In: Pruder, G. D., Langdon, C., Conklin, D. (eds.) Proceedings of the 2nd international conference on aquaculture nutntion: biochemical and physiological approaches to shellfish nutrition. Louisiana State University, Baton Rouge, p. 231-251

Rice, D. L. (1982). The detritus nitrogen problem: new observations and perspectives from organic geochemistry. Mar. Ecol. Prog. Ser. 9: 153-162

Seiderer, L. J., Newell, R. C., Cook, P. A. (1982). Quantitative significance of style enzymes from two marine mussels (Choromytilus meridionalis Krauss and Perna perna Linnaeus) in relation to diet. Mar. Biol. Lett. 3: 257-271

Sokal, R. R., Rohlf, F. J. (1969). Biometry. W. H. Freeman, San Francisco

Soniat, T. M., Ray, S. M., Jeffrey, L. M. (1984). Components of the seston and possible available food for oysters in Galveston Bay, Texas. Contrib. mar. Sci. 27: 127-141

Taghon, G. L. (1981). Beyond selection: optimal ingestion rate as a function of food value. Am. Nat. 118: 202-214

Taghon, G. L., Jumars, P. A. (1984). Variable ingestion rate and its role in optimal foraging behavior of marne deposit feeders. Ecology 65: 549-558

Trainer, D. G., Tillinghast, E. K. (1982). Amylolytic activity of the crystalline style of Mya arenaria (Bivalvia: Mollusca). Comp. Biochem. Physiol. 72A: 99-103

Urban, E. R., Langdon, C. J. (1984). Reduction in costs of diets for the American oyster, Crassostrea virginica (Gmelin), by the use of non-algal supplements. Aquaculture 38: $277-291$

Van Valkenburg, S. D., Jones, J. K., Heinle, D. R. (1978). A comparison by size class and volume of detritus versus phytoplankton in Chesapeake Bay. Estuar. coast. Shelf Sci. 6: 569-582

Ward, J. E., Cassell, H. K., MacDonald, B. A. (1992). Chemoreception in the sea scallop Placopecten magellanicus (Gmelin). I. Stimulatory effects of phytoplankton metabolites on clearance and ingestion rates. J. exp. mar. Biol. Ecol. 163: 235-250

Ward, J. E., Targett, N. M. (1989). Influence of marine microalgal metabolites on the feeding behavior of the blue 
mussel Mytilus edulis. Mar. Biol. 101: 313-321

Widdows, J. (1978). Combined effects of body size, food concentration and season on the physiology of Mytilus edulis. J. mar. biol. Ass. U.K. 58: 109-124

Widdows, J., Hawkins, A. J. S. (1989). Partitioning of rate of heat dissipation by Mytilus edulis into maintenance, feeding, and growth components. Physiol. Zool. 62: 764-784 Willows, R. I. (1992). Optimal digestive investment: a model

This article was submitted to the editor for filter feeders experiencing variable diets. Limnol Oceanogr. 37(4): 829-847

Wright, S. H. (1982). A nutritional role for amino acid transport in filter-feeding marine invertebrates. Am. Zool. 22: $621-634$

Wright, S. H. (1988). Amino acid transport in the gill epithelium of a marine bivalve. Comp. Biochem. Physiol. 90A: $635-641$

Manuscript first received: January 12, 1993

Revised version accepted: March 15, 1993 